\title{
Utility of basic research in plant/crop physiology in relation to crop improvement: a review and a personal account
}

\author{
Mabrouk A. El-Sharkawy* \\ Centro Internacional de Agricultura Tropical (CIAT), Cali, Colombia. Present address: A.A.26360, Cali, Colombia \\ *Corresponding author: elsharkawy@telesat.com.co
}

Received: 22 February 2007; Accepted: 27 February 2007

Agricultural research and development plays an essential role in a nation's economic development, providing for food security for an ever-increasing population. In developed countries, the gap between potential and actual yield is largely closed because of a combination of advanced technologies, high-yielding new varieties and the application of agrochemicals in highly mechanized production systems. In most of these countries, agricultural production exceeds national demand, resulting in excess products for export. In many of the developing countries, however, agricultural productivity is still far below what it should be because of multiple technical and socio-economic constraints. Food deficits are the norm in poor and middle-income countries, requiring expensive food imports. To partially alleviate this situation, agricultural research must be strengthened. As branches of basic sciences, plant and crop physiology have often been criticized for being non-effective in translating their findings into improving crop productivity, which would enhance agricultural progress. This paper addresses this issue by presenting an assessment of past achievements of physiological research and their impacts on crop improvement and food production. Shortcomings and limitations of isolated, non-relevant research are discussed, along with scientist views on how effective physiological research should be conducted and integrated within breeding-based multidisciplinary research teams. Examples of successful research in crop physiology and their contributions towards increasing crop productivity are given. All this points to the need for steadfast funding of basic research by public and private sectors of developed countries.

Key words: agriculture, breeding, $\mathrm{C}_{4}$-photosynthesis, drought-tolerance, ecophysiology, ecosystems, hormones, photoperiod, productivity, soil, water stress

Utilidade da pesquisa básica em fisiologia vegetal e em fisiologia da produção em relação ao melhoramento das culturas: uma revisão e uma análise pessoal: A pesquisa e o desenvolvimento agrícola têm função essencial no desenvolvimento econômico das nações, provendo segurança alimentar para uma população em constante crescimento demográfico. Em países desenvolvidos, as lacunas entre a produção potencial e a produção real são sobremodo estreitas, devido a uma combinação de tecnologias avançadas, novas variedades altamente produtivas e aplicação de agroquímicos em sistemas de produção altamente mecanizados. Na maioria daqueles países, a produção agrícola supera a demanda nacional, resultando em excedentes para a exportação. Em muitos países em desenvolvimento, entretanto, a produtividade agrícola está ainda muito abaixo de seu potencial devido a limitações técnicas e sócio-econômicas. Déficit alimentar é a norma em países pobres e subdesenvolvidos, os quais requerem vultosas importações de alimentos. Para aliviar parcialmente essa situação, pesquisas de cunho agrícola devem ser reforçadas. Como ramos das ciências básicas, a fisiologia vegetal e a fisiologia da produção têm sido freqüentemente criticadas por não traduzirem seus resultados de pesquisa em melhoria da produtividade. Este artigo é focado nesse tema, apresentando uma avaliação das realizações pretéritas da pesquisa fisiológica e de seus impactos sobre o melhoramento das culturas e sobre a produção de alimentos. Discutem-se deficiências e limitações de pesquisas isoladas e de pouca relevância, juntamente com opiniões do cientista sobre como pesquisas efetivas na área da fisiologia devem ser conduzidas e integradas dentro de equipes de pesquisa multidisciplinares associadas ao melhoramento vegetal. Exemplos de pesquisas de sucesso na fisiologia da produção e suas contribuições para aumentar a produtividade agrícola são apresentados. Todos esses aspectos apontam para a necessidade de pronto financiamento da pesquisa básica por setores públicos e privados de países desenvolvidos.

Palavras-chave: agricultura, ecofisiologia, ecossistemas, estresse hídrico, fotoperíodo, fotossíntese $\mathrm{C}_{4}$, hormônios, melhoramento, produtividade, solo, tolerância à seca 


\section{INTRODUCTION}

At present, there is an increasing agricultural pressure on the limited natural resources, particularly prime land and fresh water, in many developing countries (Postel, 1984; Wallace, 2000). This situation will be further aggravated by the high rate of population growth, due mainly to the high fertility rate in most developing countries, coupled with changes in consumption habits that would result in high demand for food and feed in the coming few decades (Sasson, 1990; Blake, 1994; Leisinger, 1995; Cohen, 1997). In view of this pressure it is necessary to formulate and adopt sound agricultural policies for sustainable development aided by well-planned research strategies, and efficient delivery systems for needed agricultural services and improved technologies (Buringh, 1977; Wortman and Cummings; 1978; Wortman, 1981). In the 20th century, agricultural research has contributed immensely in closing the large gap between potential and actual crop productivity in developed countries of the temperate zones (Loomis and Connor, 1992). This was largely due to the development of highyielding new cultivars and the use of agro-chemicals in highly mechanized large-scale farming systems, resulting in greatly increased agricultural output per farmer and land area (Wittwer, 1979; Critchfield, 1982).

In developing countries, however, agriculture is still a village-based system with smallholders and laborintensive small farms. With the exception of a few cases, such as the Nile Valley of Egypt (El-Tobgy, 1974), where productivity is high under irrigation and fertilizer use, farm yields are largely suboptimal. Besides the low yields, per capita annual growth rate of food production in lowand middle-income developing countries is declining and still lagging behind the annual population growth rate (Leisinger, 1995). It is anticipated, therefore, that most increases in agricultural production will come (or should come) from developing countries, particularly those in the tropics and subtropics where farm yields are far below their potential.

Low productivity in most developing countries is attributed mainly to lack of appropriate and improved technologies, as well as the existence of biotic and abiotic stresses (Leisinger, 1995). Added to that, in many developing countries, especially in Africa, Asia and Latin America, a large share of the agricultural production is carried out by resource-limited small farmers who are discriminated against by unfavorable national socioeconomic policies (Chambers and Jiggins, 1987; Chambers et al., 1989). In this case, there are needs not only to develop more knowledge and better-adapted crop cultivars but also to alleviate the grievances of the small poor farmers in particular and the rural sectors in general. This requires introducing and adopting the necessary changes and reforms in agricultural and socio-economic policies (Leisinger, 1995).

The 2006 Nobel Peace Prize was awarded to the economist Muhammad Yunus and his Grameen Foundation in recognition of his successful pioneering efforts to help some of the poorest farmers, first in his own country, Bangladesh, and later in several other developing countries in Asia, Africa and Latin America. This was done by creating a simple micro-credit financial system without the required inhibiting conditions demanded by traditional commercial banks. The creation and effectiveness of Yunus Grameen Bank (or village bank) illustrated how simple and carefully planned financing schemes can make a difference in obviating the many socio-economic constraints and in alleviating poverty in rural sectors. In addition, it illustrated that villagers are indeed responsive to new ideas and are willing to adopt socio-economic changes once they perceive their positive consequences (Critchfield, 1982). The agricultural productivity of these resource-poor farmers has been enhanced and resulted in a better standard of living, which in turn increased their demands for improved and appropriate technologies.

Thus, higher priority in agricultural research should be given by both national and international institutions to solving small farmer's problems that constrain crop productivity as well as the sustainability of agricultural systems (Chambers et al., 1989), particularly in countries where national programs are weak or nonexistent. Involving farmers in the research process, via the new approach of "farmer participatory research", is necessary for increasing research effectiveness and applicability of new technologies (Hellin et al., 2006; Leisa, 2006). These research efforts would be further enhanced by linking and integrating the various branches of science from the molecular level (i.e., reductionistic approaches) to the whole-plant and ecosystem levels (i.e., holistic approaches) in 
interdisciplinary/interinstitutional teams (Loomis et al. 1979; Loomis and Connor, 1992; Loojin, 1999; Delmer, 2005). Moreover, the use of available research tools in molecular biology and genetic engineering, as well as crop modeling, is essential for increasing efficiency of research (Kramer, 1980; Thornley and Johnson, 1990; Boote and Loomis, 1991; Shorter et al., 1991; Cohen, 1993; Evans, 1993b; Leisinger, 1995; Jackson et al., 1996; ElSharkawy, 2005).

The standard textbook, Crop Ecology: productivity and management in agricultural systems by Loomis and Connor (1992), is an invaluable reference on the ecophysiological principles, mechanisms, concepts, and problems encountered in the production processes in various ecosystems of crops and pastures. Moreover, it follows quantitative and analytical approaches based on the biophysics, chemistry and mathematical algorithms underlying photosynthesis, productivity, soil-plantatmosphere relationships and water and nutrient uses. An equally important recent reference book on various crops and plantations is the Handbook of Industrial Crops edited by Chopra and Peter (2005). This book brings together and assembles a vast amount of information accumulated by extensive research on perennial crops by eminent scientists in many countries, particularly in the tropics. Information given includes many aspects of crop research such as germplasm conservation, cytogentics, DNA sequences, breeding, ecophysiology and soil-plantwater relationships in various cropping systems. These references, among many others, are useful sources of information for agronomists, plant breeders and plant ecophysiologists.

Following up on the recent reviews where field research was emphasized in order to bring direct impact on crop productivity (El-Sharkawy, 2004, 2005, 2006), this review discusses and emphasizes the long-debated role of physiological research in agricultural progress in general and in crop improvement and food security in particular.

\section{AN OVERVIEW OF THE ROLE OF PHYSIOLOGICAL RESEARCH IN CROP IMPROVEMENT}

Why physiological research is criticized: As branches of basic sciences, plant and crop physiological research are often criticized as being detached from practicality and its role in improving agricultural productivity is considered limited. This criticism is due mainly to: (1) a lack of coordination, in some cases, with relevant breeding programs; (2) an inability to translate most research findings into yield gains in the field; (3) and a lack, in most cases, of applicable techniques in plant breeding where large genetic populations must be handled.

The irrelevance of some physiological research is better illustrated by studies done in isolation under mostly unrepresentative environments, particularly when plants were grown in pots kept indoors, conditions that deviate from those under which crops are normally grown (El-Sharkawy, 2004, 2005, 2006). Long et al. (2006) reported on a large number of field trials conducted on some $\mathrm{C}_{4}$ and $\mathrm{C}_{3}$ crops across locations and countries using the sophisticated Free-Air $\mathrm{CO}_{2}$-Enrichement (FACE) technique as a tool for studying long-term responses to elevated atmospheric $\mathrm{CO}_{2}$. The percent increases in both photosynthesis and yield were much less than was previously observed with plants grown in pots in greenhouses, suggesting acclimation problems as pointed out by El-Sharkawy (2005). Kramer (1981) in discussing effects of elevated $\mathrm{CO}_{2}$ on photosynthesis and dry matter production concluded that: "even though increasing the concentration of $\mathrm{CO}_{2}$ to $600 \mathrm{ppm}$ increases the rate of photosynthesis of many plants in phytotron and greenhouse experiments, there is no assurance that similar increases will occur on a global scale where water and nitrogen (N) already often limit growth". Arp (1991), on the other hand, argued against the use of plants grown in small pots where root growth is restricted and causes a buildup of assimilates, resulting in feedback inhibition of photosynthesis. More recently, Ronchi et al. (2006) found that in Coffea arabica plants grown in small-size pots, net leaf photosynthesis decreased (i.e., down-regulated) as compared to plants grown in larger pots. Such a downregulation was due mainly to reduction in Rubisco activity rather than to build-up of end products or changes in stomatal conductance. Decreases in Rubisco activity was attributed, in turn, to inadequate $\mathrm{N}$ content in leaves despite sufficient $\mathrm{N}$ being available in the small pots.

Others (Bernston et al., 1993; McConnaughay et al., 1993), apparently, do not support abandoning decades of nonfield-based research and suggested that similar 
conditions that might restrict root growth exist in field. Nevertheless, these findings have significant implications for predicting responses to climatic changes via crop/ecosystem modeling based on data from inappropriately grown plants. In addition, it points to how huge resources and efforts could be wasted with the risk that science and scientists may lose the support and interest of society. El-Sharkawy (2005) cautioned against the risk of using data from inappropriately grown plants and its use in crop modeling to predict responses of cropping systems to the environment without proper field calibration. Long et al. (2006) stated that private sector financial support for this kind of research would be hard to get. Additional reading concerning such problems together with the role of physiological research in improving productivity of crops in different ecosystems and environments can be also found in the extensive volume published by the Crop Science Society of America (Buxton et al., 1993).

Scientist assessment of the role of physiological research and how it could be more effective and relevant: Some eminent scientists, particularly plant physiologists, have demonstrated and discussed the utility of properly conducted physiological research and its contribution to improving agricultural productivity (Evans, 1977, 1993a,b; Kramer, 1980; Schrader, 1980; Whan et al., 1993). Schrader (1980) discussed the potential of biochemistry and plant physiology in improving crop productivity and indicated that multidisciplinary research is the most effective means to ensure sound research products. He pointed out that a breeding scheme based on physiological and biochemical traits that make efficient use of nutrients, water, $\mathrm{CO}_{2}$ and solar energy probably will enhance, but not replace or substitute for, conventional breeding techniques. Identification and incorporation of useful plant traits should lead to a more efficient metabolic system and better-adapted and stress-tolerant cultivars. He also outlined the many obstacles constraining the application, in breeding programs, of some of the many important discoveries in biochemistry and plant physiology. There is a need to close the gaps separating the reductionistic approaches employed in basic research and the holistic approaches followed in plant breeding and crop management studies. Because of increasing competition for often limited research funds, integrated approaches involving multidisciplinary teams have a better chance of being funded than those tailored around a sole discipline narrow in scope and aims.

Kramer (1980) stated that plant physiology is a powerful science and has the potential to contribute to agricultural progress. Nevertheless, he stated that crop yields are limited more often by unfavorable environments than by lack of capacity in physiological processes. Therefore, relevant research should be done first in the field where the many limiting environmental factors can be identified, followed by laboratory research under controlled conditions to elucidate physiological processes/mechanisms underlying plant responses to those limiting factors. Accordingly, this approach requires interdisciplinary teams composed of agronomists, soil scientists, meteorologists, physiologists, and breeders who are willing to cooperate in solving specific problems.

The extensive research conducted in phytotrons, such as the one called "CERES" (controlled environment research) in Canberra, Australia, have shown both its scientific and utilitarian value in complementing field studies (Evans et al., 1985). In addition, phytotron research at Duke University, USA, on photothermal effects on several crop plants has helped in elucidating the genetic control of flowering (Quinby et al., 1973; McBlain et al., 1987). El-Sharkawy et al. (1992a, 1993), working in the tropics, studied the effect of temperature during plant growth on cassava leaf photosynthesis. Several cassava cultivars from different habitats were grown in large pots in the open, taking advantage of temperature variations at different altitudes within short distances, which obviated the need for phytotrons. The research revealed important information on photosynthetic responses to measurement-temperature and photon flux density under laboratory controlled conditions. Large differences were found among sets of leaves, of the same plants, that had developed under warm and cool climates. Cool-climate leaves with very low photosynthetic rates were able to partially recover their photosynthetic capacity after acclimation for several days in a warm climate. Both cool-climate and then warmacclimated leaves had significantly lower photosynthetic rates, and were light saturated at much lower photon flux density, as compared with those observed in leaves developed in the warm climate. Moreover, genotypic 
differences in response to growth-temperature were apparent with cultivars from low-land, warm humid climates, such as in Brazil, which presented the highest rates in all sets of leaves compared to high-land, cool humid climate cultivars. Screening for cold-tolerance among a larger group (107 clones) of accessions was conducted under representative field conditions at highland locations (mean annual temperature $\approx 18^{\circ} \mathrm{C}$ ) using portable infrared gas analyzers. Several clones were identified with significantly higher leaf photosynthetic rates, as compared with the trial mean, due mainly to nonstomatal factors (i.e., biochemical/anatomical leaf traits) (El-Sharkawy, 2006). These selected clones were used in a crossing program for breeding for new more cold-tolerant cultivars.

Evans (1993b), discussing the role of physiology in enhancing yield potential, stated that: "as a crop physiologist, I should like to be able to conclude that ideological selection, based in part on physiological understanding, will increasingly take over from empirical selection for the raising of yield potential....however, I suspect we will continue to rely mainly on empirical selection for yield potential, with molecular techniques providing a pre-concentrating mechanism analogous to the role of the $\mathrm{C}_{4}$-dicarboxylic acid cycle for $\mathrm{C}_{3}$ photosynthesis". Another quote of Evans (1977) apparently in defense of physiological research and physiologists: "plant physiologists can fairly claim to be the midwives who help agronomists, plant breeders, pathologists and entomologists to deliver the extra food required by population growth and higher living standards". Besides the great advances in the field of plant nutrition and their impacts on agricultural output for almost a century aided by expanding fertilizer use, Evans cited several interesting examples of how plant physiology is contributing to agricultural progress. Notably among these examples is how the "curiosityoriented" research conducted by the eminent Dutch plant physiologist, Frits Went, while working in the USA, had led to many discoveries in phytohormones, despite the hardships in getting funded due to the lack of vision demonstrated by Went's research evaluators.

Unfortunately, this short-sighted vision on the part of some research managers and funding agencies still prevails today, even in international research centers that are supposedly committed to the development of improved technologies needed by developing countries (Blake, 1994; Kawano and Cock, 2005; El-Sharkawy, 2006). A case in point is what has been taking place in centers like CIAT, where in the past decade it suffered from a severely reduced research budget that led to dispersion of committed and productive scientists as well as in dismantling interdisciplinary-based research programs (El-Sharkawy, 2006). Steadfast funding in support of science in general and of maintenance research in particular, as was the case with the Green Revolution, is crucial and should not be subject to political manipulation, fashionable trends and bandwagons (Simmonds, 1991; El-Sharkawy, 2006). Simmonds (1991) stated: "a bandwagon is merely the obvious response to a new idea or technique which promises well; if you can't beat 'em, join 'em. And, if the bandwagon is a good one (allied to competent publicity), it becomes a gravy-train; a seat on it virtually guarantees funds, grants and other goodies such as easy (and not too roughly refereed) publications". An example is the crop modeling effort, the early progress of which suffered growing pains. This effort with an emphasis upon new research represents a powerful tool for integrating physiological research for an understanding of how crop or ecosystems behave and which traits to select for.

The research on Arabidopsis thaliana (Somerville and Ogren, 1980; Somerville et al., 1982), for example, was a breakthrough in both plant physiological and molecular genetic research, providing scientists with a powerful and easy to manipulate (via mutations) plant system. It enhanced plant genomic research as well as genetic engineering that complemented conventional breeding methods. However, it has also become an unnecessarily attractive bandwagon, where research funds have been redirected mostly towards molecular biology at the expense of essential applied and basic research on crop improvement, cropping systems and whole-plant biology (Ryder, 1984). Worse, this fashionable trend in science has caused many higher education institutes, especially in developed countries, to close down some disciplines and whole departments dealing with commodity improvement and cropping system research. Molecular biology research is effective only when it complements and integrates with other fields of science, since the technology outputs must be tested in whole-plant and within relevant cropping systems under prevailing 
environments (Francis, 1989; Cohen, 1993; El-Sharkawy, 2005). In general, plant responses to environmental conditions are complex in nature and relate to many plant morphological, anatomical, physiological and biochemical traits, processes and mechanisms, which are controlled by multiple genes probably located and expressed in different sub-cellular compartments, array of cells, tissues and organs. "Cutting and pasting" one or two genes seems practical for simple-inherited traits, but such effort might be ineffective when dealing with complex and quantitatively-inherited traits. Therefore, the powerful techniques of recombinant DNA and DNAmarkers that locate and transfer genes and gene-loci of interest (Brown, 1983; Tanksley et al., 1989; Paterson et al., 1991; Potrykus, 1991; Day, 1993) would require better understanding of - and linking to - other fields of science, particularly plant breeding and genetics, biochemistry and physiology (Ryder, 1984; Ceccarelli and Grando, 1993; Hunter, 1993; Bartels and Nelson, 1994; Bohnert et al., 1995). Ryder (1984) wisely remarked: "I believe very strongly that the technology we call genetic engineering and its attendant sciences and technologies should be pursued. The potential benefits are worth the pursuit. I do not wish to see the support of genetic engineering undertaken, however, on the basis of broad edicts, at the expense of other aspects of plant breeding and its attendant sciences and technologies".

From a breeding perspective, however, and after surveying and assessing a long list of published physiological research, Jackson et al. (1996) found most research results have little value for breeding programs. They outlined the necessary steps and attention needed to make better use of physiological information in crop breeding focusing on the need to work with relevant genetic populations, close integration of the physiological research within an active breeding program and pointed to the dangers of narrow pre-determined directions in the physiological research done in isolation. Whan et al. (1993) also emphasized the need of integrating breeding and physiological research, and provided a working example for such cooperation in Western Australia. The effort resulted in increasing grain yield of wheat and in the adaptability of cultivars to moisture-limited environments. Similar experiences where physiological research played an important role in breeding programs took place at other laboratories such as the International Rice Research Institute in Philippines (IRRI) (Yoshida, 1972; IRRI, 1990; Virmani, 1996).

Early $20^{\text {th }}$ century interdisciplinary-integrated cotton research in Egypt and USA: In this regard, it is noteworthy that about a century ago a major research program on improvement of the Egyptian long-staple cotton (Gossypium barbadense L.) was already established on the basis of a multidisciplinary approach (Balls, 1907, 1915). Balls (1907) pioneered the application of the then rediscovered Mendelian genetics as well as in integrating crop physiological/agronomical research within the cotton breeding program at Giza Station, with several substations across the country to test cultivar adaptability to variations in atmospheric and edaphic factors (i.e., genotypic x environment interaction). Balls (1915) discussed in great detail the growth of cotton (including studies on stomatal behavior in reaction to cultural practices and climate) as affected by the heavy clay soils, with moderate levels of salinity, in the Nile river delta. He reported on the effect of the water table, after it rose to immerse the lower half of the root system, on fiber quality. He stated that, "bolls opening ten days later will have weak but long lint, those opening five weeks later will have lint both weak and short, with a high ginning out-turn (i.e., lint percentage in seed-cotton), and those opening seven weeks later will be worthless in all respects". Thus, fiber quality was strongly affected, in different degrees, by soil and plant water content at different stages of growth, a topic still researched by modern-day better-equipped plant breeders, physiologists and soil scientists.

Similarly, significant contributions of physiological research to upland cotton (G. hirsutum L.) breeding and improvement were made by Eaton and coworkers in USA (Eaton, 1927, 193 1a,b, 1955; Eaton and Ergle, 1952, 1954). They studied the influence of various plant traits, such as habit of branching, flowering, fruiting, and leaf canopy shape on cotton growth, yield and fiber quality. Manipulating fruiting load through fruit structure removal (i.e., removal of flower buds or squares, flowers or young bolls) increased plant size with consistent yield improvement, provided that removal of fruiting forms was not severe and prolonged. Defloration and defruiting also resulted in a modified plant shape that resembled determinate-type cotton cultivars that tend to have a 
shorter fruit-setting period (Eaton, 1927, 1931). Moreover, they studied the influence of soil moisture, partial defoliation and light intensity on fiber properties, carbohydrate and nitrogen levels of cotton plants. Eaton and Ergle (1952) concluded that fiber strength was improved by the plant enzyme system favoring rapid carbohydrate utilization, and by modifications resulting in high carbohydrate supply in cotton. In addition, a positive association between the intensity of light that reached the plants and carbohydrate levels was demonstrated (Eaton and Eargle, 1954).

This early physiological research has significant implication for breeding strategy as well as management practices of upland cotton cropping systems. It had led, for example, to the search for leaf types, such as okratype small and narrow leaves, that may increase light penetration deep within canopy and reduce boll rots enhanced by increased humidity (Andries et al., 1969, 1970; Kennedy et al., 1986). Furthermore, the research has implications for the potential effects of leaf photosynthetic capacity and canopy structure that may enhance the supply of carbohydrates required for higher yield. Recent field studies in the USA with eight cotton genotypes differing in leaf size and shape showed that the two lines with smaller and narrower leaves ("okra leaf trait") had higher photosynthetic rates per unit leaf area at all sun light intensities imposed by shading than the other six genotypes with normal broad leaves (Pettigrew et al., 1993; Pettigrew, 2004a,b). Compared to normal leaftype cottons, okra leaf-type varieties, on average, exhibited $30 \%$ higher photosynthetic rate per unit leaf area, $14 \%$ greater light-adapted PSII quantum efficiency and $14 \%$ greater photosynthetic electron transport rate. In addition, non-photochemical quenching was $11 \%$ lower in the okra leaf-type genotypes relative to normal leaftype ones. It was suggested that the concentration of photosynthetic machinery, as demonstrated by about a $13 \%$ increase in chlorophyll concentration in the okra leaf-type varieties as a result of about $37 \%$ decrease in single leaf area, may partially explain the higher photosynthetic rates. It is possible, therefore, that in cotton with narrow leaves, when planted with optimum density to compensate for reduction in single leaf area, canopy light interception would be increased, probably with consequent increases in canopy photosynthesis and yield.
Training young scientists with multidisciplinary skills can enhance integration and utility of research: a personal experience: Fifty years later, Balls' experience and approach in scientific research had a great influence on my professional formation as a young student granted an Egyptian government scholarship and aspiring to study cotton in the USA. Knowing that on my return to Egypt I would probably be stationed at the same place as Balls, where the last British experts left in the early 1950's, I decided to combine in my graduate program both a breeding and a physiological background at two different institutes. One institute, Louisiana State University, did research on breeding of short-staple upland cotton, $G$. hirsutum L., rain-fed in a hot humid climate, but not cultivated in Egypt. And the second, the University of Arizona, did research on physiology/breeding of longstaple cotton, G. barbadense L., irrigated in hot dry desert conditions with intense solar irradiance, as in Egypt. After completing my M.Sc. thesis on the genetic analysis of $F_{1}$ and $F_{2}$ progenies of a cross between widely different and nearly homozygous parents and proving that both fiber strength and fiber elongation are quantitative traits, and probably controlled by more than 11 and five genes, respectively (Tipton et al., 1964a,b), I decided to change direction. That may have seemed awkward to my fellow colleagues and surprising for my thesis supervisor at Louisiana State University, since we had already harvested sample bolls from $\mathrm{F}_{3}$ progeny lines that awaited fiber analysis for a PhD thesis that would have taken less than two years, whereas changing a major field of study and institution would certainly take longer. Permission to do so was granted by my Egyptian boss, the Under Secretary, Ministry of Agriculture (El-Tobgy, 1974). It happens that Hassan El-Tobgy, a geneticist trained at the University of California, recruited me in 1958, a month after I graduated from the University of Alexandria with a B.Sc. in agronomy, as his research assistant at the National Research Center, Doki, Giza. I spent two years doing cytological studies for a chromosome atlas of the Egyptian desert flora as well as being trained in cotton genetics under the supervision of a Dutch-Egyptian lady geneticist, Handrina Anna.

Was the shift worth the trouble I encountered at the University of Arizona because I insisted on pursuing my own research project on cotton physiology and photosynthesis? I guess the answer is yes as I was 
fortunate enough to meet a young assistant professor and physiologist, John D. Hesketh, who joined the university two months later and together we sailed into the unknown against hostile winds and waves (ElSharkawy and Hesketh, 1986). After completing the PhD with several pre-publications and conference presentations, I joined the physiologists R.S. Loomis and W.A. Williams, University of California, Davis (ElSharkawy et al., 1967, 1968). Perhaps, this story might help young students, particularly those from developing countries with limited resources and support for science, not to be inhibited by whatever they may consider to be unfavorable conditions.

Day (1993), in discussing the role of molecular biological advances in producing improved cultivars via traditional breeding, emphasized the importance of integrating the two disciplines as well as training future plant breeders and molecular biologists with skills in both fields of specialization. This kind of integration, while training young scientists, will enable them to easily appreciate working within interdisciplinary research teams, and it should be encouraged across other scientific disciplines.

Why should mavericks and dissenters be tolerated? a few examples: In the long history of science there are examples indicating that maverick behavior by some scientists, aided by a heavy dose of serendipity, often leads to major discoveries and breakthroughs. A case in point is my personal experience in the 1960's while doing my $\mathrm{PhD}$ studies at the University of Arizona within a pioneering breeding/physiology research project. We studied factors limiting leaf photosynthesis in relation to productivity among a wide range of species, including cotton, wheat, barley, oats, sunflower, sugar beet, tropical grasses such as maize and sorghum, as well as a weed amaranth, pigweed (Amaranthus palmeri). That research has led to many important and surprising discoveries in the $\mathrm{C}_{3} / \mathrm{C}_{4}$ syndrome (El-Sharkawy and Hesketh, 1964a,b, 1965; El-Sharkawy et al., 1965; Muramoto et al., 1965). Working in hot sunny and dry environments, we measured leaf photosynthesis of whole irrigated cotton germplasm in the field and found greater rates, with larger variations among species and cultivars, than those obtained in potted and greenhouse-grown plants. For example, leaf photosynthesis, as measured in normal air and intense light, of cotton grown indoors was saturated at less than $50 \%$ of full sunlight; by contrast, the same plants left outdoors showed almost doubled gas exchange rates, thus responding to much higher irradiance levels in addition to showing an upward shift in their optimum leaf temperatures for maximum photosynthesis (El-Sharkawy and Hesketh, 1964a; ElSharkawy et al., 1965). These important observations led us to coin this phenomenon "the greenhouse effect".

All plant physiology textbooks written up to late 1950 's and early1960s showed leaf $\mathrm{CO}_{2}$ exchange rates saturated at less than $40 \%$ of full sunlight and with much smaller rates than those we recorded for the same species either grown in large pots but left outdoors or in fieldgrown plants. I recall when we reported such results at one of the annual meetings of the American Society of Agronomy in 1964, an eminent meteorologist-ecologist sharply criticized us for using the foot-candle unit for light measurements, ignoring the fact that the foot-candle unit was still used in research reported in so-called prestigious journals like the Proceedings of National Academy of Sciences at the time. At another meeting of the International Botanical Congress held in USA, 1966, one eminent photosynthesis biochemist raised hell in a room packed with more than 200 international scientists. This was because we presented results showing leaves of maize and grain amaranth (A. edulis) with no apparent photorespiration and with the unique leaf Kranz anatomy. This species was the third discovered $\mathrm{C}_{4}$ member in the family Amaranthaceae and known to be domesticated and largely cultivated by the Aztecs and the Incas before Cortez and still cultivated today in minor acreages in the Andean highland of Argentina, Peru and Bolivia (Connor et al., 1980; Saunders and Becker, 1983; BOSTID, 1984; ElSharkawy and Hesketh, 1986). Our conclusion was that these species were capable of reassimilating their internal respiratory $\mathrm{CO}_{2}$ via a very efficient photosynthetic machinery (El-Sharkawy et al., 1967, 1968). That was done shortly before the $\mathrm{C}_{4}$ biochemical photosynthetic pathway was elucidated (Hatch and Slack, 1966, 1970).

Moreover, both lab and field work allowed us to correctly link leaf anatomy features, for the first time, with photosynthetic characteristics in both monocot and dicot species adapted to different environments. That research was unfortunately discriminated against by both the department involved and the scientific establishment during my reporting to the several 
professional meetings I attended in the USA as discussed above. Yet, one publication (El-Sharkawy and Hesketh, 1965) highlighting some of these discoveries was awarded a Citation Classic in 1986 by the Institute of Scientific Information (ISI), and was among the 20 most cited articles published in Crop Science up to 1990 according to the ISI evaluation (E1-Sharkawy and Hesketh, 1986; Garfield, 1992, http://www. garfield.library.upenn/edu/classics 1986 / A1986C891300001.pdf). Four other companion publications were equally cited, except more recently by some photosynthesis biochemist researchers, indicating the originality and significance of the research. In conclusion, I may say that our research was crucial and laid a foundation for subsequent anatomical, physiological and biochemical studies that elucidated the details of the now called $\mathrm{C}_{4}$ photosynthetic pathway, plus the fact it stimulated a wave of extensive photosynthetic research afterwards (Hatch and Slack, 1966, 1970; Jackson and Volk, 1969, 1970; Laetsch, 1974).

Another widely known example illustrating discrimination in science is the pioneering work of Barbara McClintock, USA, conducted from 1930 to 1960 , on maize cytological behavior, and chromosomal aberrations and breakage, in relation to variations in kernel's color that had led to the discovery of the socalled transposable or jumping genes (i.e., mobile genetic elements). These findings were contrary to the then widely held concept of physical immobility of genetic elements across their chromosomal sets (i.e., genes cannot move) (McClintock, 1942, 1950, 1978; Freeling, 1984; Peterson, 1993). McClintock, single-handedly, conducted her research using simple light microscopic and laboratory smearing-staining techniques in combination with making crosses and observing segregations in field trials. Despite the great contribution to maize genetics early on, her work received little citation at the time in relevant books (as I may recall from my graduate course on cytogenetics in 1960's). It was also discriminated against by the mainstream geneticists for a long period until the much later advances in DNA research, and particularly the discovery of restricting enzymes, had confirmed McClintock's discoveries. These discoveries pointed to mechanisms of genetic variations, and also have laid the foundations for molecular genetic research and for the development of genetic engineering technology, i.e., gene splicing and pasting. McClintock was awarded the Nobel Prize for Medicine and Physiology in 1983 in recognition of her contribution.

More recently, Craig Ventor's experience with the human genome research project is another striking example of how a dissenting scientist can make a difference. By breaking away from the mainstream human genome project and taking advantage of more efficient, but expensive techniques for genomic sequences, Ventor was not only able to enhance the efficiency of research output in record time but also made it more cost-effective and cheaper, thereby saving taxpayer's money. Furthermore, his techniques have aided significantly in studies of plant and crop genomes.

I share, to a certain extent, some of the arguments, concerns, and conclusions discussed above. But it is necessary here to point out a few of the many positive achievements and contributions of basic research in the fields of plant and crop physiology that have been translated so far into gains in agricultural productivity through plant breeding and management of cropping ecosystems. Furthermore, in view of the increasingly changing global climate, the role of plant and crop physiological research in characterizing and predicting responses of a given plant and crop species as well as natural and agricultural ecosystems performances under these dynamically changing environmental conditions will be even greater (Hesketh et al., 1984; Begonia et al., 1987,1996,1999; Bazzaz, 1990; Besford et al., 1990; Teramura et al., 1990; Idso et al., 1991; Ziska et al., 1991; Acock and Acock, 1993; Chen et al., 1993, Gifford and Morison, 1993; Hall and Allen, 1993; Patterson, 1993; Sinha, 1993; Rosenzweig, 1993; Rosenzweig and Parry; 1994; Bunce and Sicher, 2004; Sholtis et al., 2004; Long et al., 2006).

\section{SOME EXAMPLES OF HOW PHYSIOLOGICAL RESEARCH HAS BENEFITED CROP PRODUCTIVITY}

Role of growth analysis, leaf area index, crop light interception models and biological plant ideotypes: The early British work on leaf area development, leaf area index, crop growth rate, and net assimilation rate (Watson, 1947, 1952), and the theoretical analysis by the Japanese scientists (Monsi and Saeki, 1953, Saeki, 1960) 
of crop irradiance interception in relation to canopy photosynthesis laid a foundation for crop modeling (de Wit, 1965; Duncan et al., 1967; Duncan, 1973; Loomis et al., 1979; Whisler et al., 1986; Penning de Vries et al., 1989; Boote and Loomis, 1991; Cowling and Field, 2003) and significantly increased our insights on how cropping systems work in response to changes in environmental factors. Moreover, desired morphological, structural and functional plant traits can be identified using this type of analysis. This has led to the proposition and formulation of the so-called plant ideotype concept (i.e., ideal phenotype) for plant breeding by Donald (1968) based on characterization and identification of plant traits crucial to yield formation and enhancement, and that may confer better adaptation to prevailing environments, in contrast to the traditional breeding philosophy based on the empirical approach for selecting only for yield. According to Donald's ideotype concept, pre-designed biological plant models, when developed into new cultivars, may perform better - and in a predictable manner - when grown in a particular environment. The concept was initially formulated for ideotypes targeted to favorable and less-stressful environments. Hamblin (1993) discussed the merits and shortcomings of Donald's ideotype concept, particularly when applied to stressful environments. Advances in adopting the ideotype concept for breeding cultivars adapted to various environmental conditions have been demonstrated in cereal crops such as wheat (Sedgely and Belford, 1991; Buxton et al., 1993; Hamblin, 1993; Richards, 2000), rice (Jennings, 1964; Chang et al., 1967; Athwal, 1971) and in cassava (Cock et al., 1979; ElSharkawy and Cock, 1987; Cock and El-Sharkawy, 1988; Hershey and Jennings, 1992; Kawano et al., 1998; Jennings and Iglesias, 2002; Kawano, 2003, El-Sharkawy, 2004, 2006; Kawano and Cock, 2005; Lenis et al., 2006).

Role of dwarf and semi-dwarf plant types in improving yield of cereal crops: At this point it is worth mentioning that at the time Donald's ideotype concept was first suggested in 1962, and before getting it published in 1968, wheat and rice breeders (Jennings, 1964; Vogel, 1964) had recognized the importance of semi-dwarf plant types with stiff culms that resisted lodging under high $\mathrm{N}$ levels. In these plant types, larger grain yields were attributed mainly to greater partitioning of photoassimilates towards panicles and spikes (i.e., greater harvest index, Yoshida, 1972; Gifford and Evans, 1981; Snyder and Carlson, 1984) compared with traditional varieties and land races normally with tall stems and susceptible to lodging. This work was stimulated by the earlier discoveries by Asian scientists of the Norin-10 genes controlling dwarfism in wheat germplasm and the identification of similar genotypic characteristics in rice (Chang, 1976; Begonia and Begonia, 2007). The development of many new highyielding short cultivars of cereal crops resistant to pests and diseases, in combination with improved cultural practices, resulted in the so-called Green Revolution of the 1960 's. This breakthrough in agricultural productivity saved millions from famine in several developing countries, although the benefits have not been reaped evenly across countries, regions and crops (Evenson and Gollin, 2003). Consequently, both a Nobel Peace Prize and a Japan Prize were awarded to scientists working at the international research centers in Mexico and Philippines, respectively. This is another significant example of the success in applying physiological concepts and knowledge in a crop breeding program.

Hormones and plant growth regulators: Equally important contributions of physiological research that have been translated into improving crop productivity and cropping system management can be cited in the case of the discovery of phytohormones and growth substances/regulators (Leopold and Kriedmann, 1975; Wareing, 1982; Davies et al., 1986; Mandava, 1988; Zeevaart and Creelman, 1988; Kutáček et al., 1990; Davies and Zhang, 1991; Arteca, 1995; Baker and Davies, 1995; Davis, 2005). Multinational chemical-seed companies have used the available basic knowledge on plant growth substances and have embarked on developing a wide range of herbicidal chemicals that have great implications for managing various cropping systems with a resulting higher productivity worldwide. Moreover, by applying the recently developed genetic engineering technology for inserting specific exotic genes underlying resistances to certain herbicidal chemicals into important crops such as maize, cotton and soybeans, new cultivars have been developed for commercial use (known as genetically modified crops, GMC)(Mazur and Falco, 1989). Currently these GMC are cultivated on more than 50 million hectares in several countries resulting in greater agricultural 
production. Nevertheless, objections raised against the development and release of GMC need to be addressed via careful studies assessing possible hazards and risks for the environment, human and animal safety, as well as possible negative effects such as gene exchanges with undesirable and uncultivated plant species that might have serious effects on both agricultural and natural ecosystems.

Hormones have been widely used in crops and fruit trees for flowering and fruiting manipulation and development, seed germination, and leaf defoliation such as in sugarcane plantations. They play a significant role in post-harvest physiology, processing, storage, and handling of a string of vegetable and fruit products. Careful use of hormone-based herbicides have helped in increasing productivity in a wide range of cropping systems, although concerns still remain about the longterm effects of some brands.

Plant responses to daylength (photoperiodism) and discovery of flowering genes: The early work by many plant physiologists, i.e., W. Garner, H. Allard, H. Borthwick, S. Hendricks, W. Butler, H. Cathey, R. Downs, E. Firer, M. Parker, H. Fredericq, M. Kasperbauer, H. Lane, N. Norris, H. Siegelman, E. Toole and V. Toole, at USDAARS, Beltsville, MD, USA, on responses of plants to daylength were responsible for the elucidation of the physiological and biochemical mechanisms involved. They identified a photoreversible growth regulatory system called phytochrome, a pigment that existed in two forms as controlled by red and far-red wavelengths (Quail et al., 1995; Casal et al., 1998; Kasperbauer, 1999). This pigment has important implications for crop growth, partitioning of dry matter, product quality, yield and crop management (Antonious et al., 1996; Kasperbauer and Hunt, 1998; Kasperbauer, 1999, 2000). Such basic knowledge and mechanisms were crucial in breeding crop cultivars adapted to different daylengths and eco-zones (Hay, 1990).

Morphogenesis and genetics of flowering in relation to photoperiodism and temperature in several plants and crops have been studied (Zeevaart, 1962, 1976; Hesketh et al, 1969; Murfet, 1977; Bernier, 1988). Genes controlling flowering in peas, sorghum and soybeans were identified (Quinby, 1973; Quinby et al., 1973; McBlain and Bernard, 1987; McBlain et al., 1987; Murfet 1977, 1989). This research was reviewed recently by Begonia and Begonia (2007).

Photosynthesis and its relation to crop productivity: some examples for selection and breeding for high photosynthesis in cultivated crops: In the past 60 years, the discovery and elucidation of $\mathrm{C}_{3}$-cycle biochemistry at the University of California, Berkley, was achieved by the biochemists: M. Calvin, A. Benson and J. Bassham and coworkers. Calvin was awarded the Nobel Prize in Chemistry early 1960's. Later discoveries of the many aspects of the $\mathrm{C}_{4}$ syndrome were achieved by several research groups. Most notably, by pioneering: researchers: (1) at Cornell University in field-grown maize where high leaf gas exchange rates were reported for the first time (Musgrave and Moss, 1961; Hesketh and Musgrave, 1962; Baker and Musgrave, 1964; Moss and Musgrave, 1971); (2) at the Hawaiian Sugarcane Plantations where the initial carbon fixation by sugarcane leaves was detected in $\mathrm{C}_{4}$-dicarboxylic acids (Kortschak et al., 1965); (3) at the University of Arizona on several tropical grasses such as maize, grain sorghum and bermudagrass, and on the dicot pigweed (A. palmeri) (ElSharkawy and Hesketh, 1965, 1986); (4) at the University of California, Davis, where two more dicot amaranth species, a weedy amaranth (A. retroflexus) and the cultivated, grain amaranth (A. edulis) (syn. A. caudatus 'edulis'), were discovered to possess $\mathrm{C}_{4}$ photosynthetic characteristics and have the capacity to reassimilate/ recycle respiratory $\mathrm{CO}_{2}$ in $\mathrm{CO}_{2}$-free air and light (ElSharkawy et al., 1967, 1968); (5) in Canada on detached maize leaves where photosynthesis and photorespiration were reported to be insensitive to oxygen level (Forrester et al., 1966); (6) in Australia on sugarcane leaves where the earlier work at Hawaii was confirmed (Hatch and Slack, 1966, 1970); and (7) at the University of North Carolina where maize leaves were reported to absorb oxygen under light proving the existence of photorespiration in $\mathrm{C}_{4}$ species, but at reduced rates compared to $\mathrm{C}_{3}$ species (Jackson and Volk, 1969, 1970; Raven, 1972; de Veau and Burris, 1989).

Nevertheless, there was an unnoticed earlier report published in the former USSR on $\mathrm{C}_{4}$ photosynthesis in maize (Karpilov, 1960). Karpilov demonstrated that illuminated maize leaves in air enriched with ${ }^{14} \mathrm{CO}_{2}$ fixed carbon, over a very short period, in the form of $\mathrm{C}_{4}$ - 
dicarboxylic acids malate and aspartate. Another study relevant to the discovery of $\mathrm{C}_{4}$ photosynthesis that went unnoticed by English-speaking photosynthesis researchers in the second half of the $20^{\text {th }}$ century was the German classical book on plant physiological anatomy describing botanical research done during the second half of the $19^{\text {th }}$ century (Haberlandt, 1904). Haberlandt, using the available techniques in the late 1860 's, found that sugarcane leaves possessed two types of chloroplast-containing cells: vascular bundle sheath cells surrounded with mesophyll cells tightly arranged in form of a girdle or collar, i.e., 'Kranz' in German. While describing this type of leaf anatomy and its potential function in photosynthesis, Haberlandt prophetically commented: "...whether there exists some as yet undiscovered division of labor between the chloroplasts in the sheath and those in the girdle cells". A century later, with the aid of highly advanced research tools/ methodology and knowledge, the Haberlandt prophecy was confirmed. The research done at the University of Arizona early 1960's, unaware of Haberlandt's work (ElSharkawy and Hesketh, 1965, 1986) was the first to link 'Kranz' leaf anatomy to the highly efficient photosynthetic characteristics observed in several tropical grasses and in the dicot pigweed (e.g., see Jackson and Volk, 1970; Laetsch, 1974). Laetsch (1974), in discussing structural aspects of the $\mathrm{C}_{4}$ syndrome, stated that: "Perhaps the first investigation linking Kranz anatomy with physiological aspects of photosynthesis was conducted by El-Sharkawy and Hesketh in 1965. They found that species with high photosynthetic rates, which did not leak $\mathrm{CO}_{2}$ to the environment in the light, had Kranz anatomy. These taxa are now known to be $\mathrm{C}_{4}$ plants".

Unfortunately, some mainstream photosynthesis biochemists and plant physiologists, who missed the ground-breaking research at the time, overlooked these scientific facts and failed to recognize our pioneering achievements in their later research and publications (e.g., see Hatch and Slack, 1970; Black, 1973, Hatch, 1992). Moreover, few books and proceedings on $\mathrm{C}_{4}{ }^{-}$ photosynthesis written by those biochemists and plant physiologists, particularly in Australia and the USA, not only ignored our achievements but also attributed the discovery of leaf Kranz anatomy to other workers (e.g., Black et al. 1976; Edwards and Walker, 1983; von
Caemmerer and Furbank, 1997; Kanai and Edwards, 1999). A lesson in scientific ethics has yet to be learned. The younger scientists and coming generations of science students are best advised to carefully scrutinize relevant old research and critically evaluate the literature.

These discoveries have stimulated extensive research into photosynthesis across many countries in search for applications that might improve crop productivity (Akita, 1976; Zelitch, 1975, 1982; Bassham, 1977; Austin, 1993). Until recently, however, no direct relation between photosynthesis and biological productivity has been demonstrated (Evans, 1993a). The explanation lies in the many factors and steps involved in the photosynthetic process at the sub-cellular, cellular, leaf, and crop canopy levels. Furthermore, environments under which crops are grown have strong effects on both productivity and photosynthesis, conditions that mask the possible association. Another factor behind the difficulty in detecting a direct relationship between yield and photosynthesis, particularly in cultivated cereal crops, is the fact that breeders have traditionally selected for a higher partitioning ratio of dry matter to increase grain yield (i.e., higher harvest index) rather than for higher photosynthesis (Yoshida, 1972; Evans, 1993a,b).

There are many examples of a lack of association, or even of negative trends, between yield and maximum leaf photosynthesis (as measured in normal air and saturated irradiances under favorable environments) attributed to genetics alone, and independent of environmental effects (Evans, 1993a). This conflict or 'paradox' becomes understandable and resolvable when the contributions of the various components of the photosynthetic process and other plant traits related to yield are assessed and considered during the selection process. Theoretical considerations apart, I am of the opinion that assessing leaf or canopy photosynthesis under the same field conditions where the crops are grown is the practical approach for selection for high photosynthesis in relation to productivity. Moreover, this is the approach followed so far in conventional plant breeding for yield improvement. And after all, are not the more photosynthetically efficient $\mathrm{C}_{4}$ species superior, in general, over $\mathrm{C}_{3}$ plants in both leaf photosynthetic rates and productivity? Why not then follow, in small steps, the example of nature in improving plant photosynthesis and 
productivity?

Better techniques and equipment have been developed recently that greatly enhanced progress in photosynthesis research under field conditions. The following few examples of attempts to find a direct relation between photosynthesis, as measured on single leaves in the field or using the full canopy, and yield of some important crops may illustrate both the utility of research conducted on this most important plant process and its potential in applied crop improvement research.

Nasyrov $(1978,1981)$ working in the former USSR, found a relationship between photosynthesis and productivity of cotton and related the difference in photosynthetic rates to biochemical features such as enzyme activities. He reported higher photosynthetic rates in hybrids than in the parents, and hoped to genetically modify photosynthesis based on changes in carboxylation reactions, including the $\mathrm{C}_{4}$ key enzyme phosphoenolpyruvate carboxylase (PEPC). Arjunan et al. (1990) in surveying 30 rice genotypes in India found that grain yield was positively correlated with leaf photosynthesis measured at the flowering phase in the field. Peng et al. (1991), working with 22 grain sorghum lines in the USA, found significant positive correlations between leaf photosynthesis, as measured before flowering in the field, and total biomass and yield under both well-watered and water-limited conditions. Boerma and Ashley (1988) and Ashley and Boerma (1989) studied in the USA canopy photosynthesis during seed-filling in determinate soybean genotypes and found a positive association of photosynthetic rate with yield. Rates in $\mathrm{F}_{6}$ lines derived from the high photosynthetic $\mathrm{F}_{4}$ lines showed an average $6 \%$ greater canopy photosynthesis than $\mathrm{F}_{6}$ lines derived from the low photosynthetic $\mathrm{F}_{4}$ lines. There was a positive association between canopy photosynthetic rates of $F_{4}$ lines and the mean of the $F_{6}$ lines derived from them, indicating genetic inheritance. Similar results have been reported in Canada with 12 soybean cultivars of similar maturity where leaf photosynthesis, measured during the grain-filling period, correlated positively with bean yield (Buttery et al., 1981). On the other hand, canopy photosynthesis as measured during the peak root bulking period, but not single leaf photosynthesis, was found to be positively correlated with storage root yield in sweet potato (Bhagsari and Ashley, 1990). In potato research at Idaho, USA, attempts were made to identify parental materials with high photosynthetic rates and high tuber production to be used in crossing programs. The clone (A6948-4) with both higher photosynthesis and tuber yield than the traditional cultivar Russet Burbank was identified and crossed with other clones (Dwelle et al., 1981). Balakrishnan et al. (1987), working with several pigeon pea cultivars growing in the field during three different seasons in India, found significant positive correlations between leaf photosynthetic rates and total dry matter and seed yield, when photosynthesis was measured at the first flowering phase.

Hesketh et al. (1981) evaluated leaf photosynthesis behavior in the field in the USA, for a large group of soybean genotypes varying in area per nodal unit and maturity classes. They measured $\mathrm{CO}_{2}$ exchange rate per unit leaf area (CER) under high photon flux density on intact plants, as well as the activity of the $\mathrm{C}_{3}$ enzyme Rubisco. The CER values were highest for fully expanded leaves during the rapid pod-filling period. In addition, CER was positively correlated with Rubisco activity, specific activity, soluble protein, specific leaf weight and chlorophyll content, but was negatively correlated with area per leaf unit that may imply a dilution in Rubisco concentration and in other photosynthetic components as leaf area increased. The authors concluded that photoperiod or maturity genes for leaf area growth may interact with genes controlling CER that would result in major differences in CER values among soybean genotypes. These data illustrate the "trade off" between CER and leaf area and point to the importance of using canopy photosynthesis as the criteria for yield enhancement in this case.

In comparing a group of old and improved highyielding spring wheat cultivars in Israel, Blum (1990) found that CER of detached flag leaves and photosynthetic capacity as defined by the ratio of CER/ $C_{i}$ (intercellular $\mathrm{CO}_{2}$ ), when estimated at high photosynthetically active radiation (PAR), varied significantly among cultivars. The recently developed high-yielding cultivar V652 had a higher maximum CER, higher $\mathrm{CER} / C_{\mathrm{i}}$ and greater leaf water-use efficiency (WUE) (dry matter/water loss) at high PAR than older and lower-yielding cultivars, suggesting an upward genetic shift in photosynthetic characteristics when selection for yield was performed under the desert high-radiation 
conditions. Also, there is evidence that yield enhancement in the semi-dwarf high-yielding wheat cultivars, as compared to tall individuals, may be attributed to both high harvest index coupled with a strong grain sink and high leaf photosynthetic rates (Lupton, 1972; El-Sharkawy, 1975; Ruckenbauer, 1975; Richards, 2000). Moreover, research at the International Maize and Wheat Improvement Center (CIMMYT), Mexico, on assessing the physiological basis underlying yield improvements in semi-dwarf spring wheat cultivars released between 1962 and 1988, revealed some interesting findings (Fischer et al., 1998). Averaged over three years, measurements of stomatal conductance $\left(g_{s}\right)$, maximum photosynthetic rate per unit flag leaf area measured in the field in normal air and saturating PAR, and canopy temperature depression (CTD) were closely and positively correlated with progress in the six-year mean yield, with $g_{s}$ having the greatest correlation. Carbon-13 $\left({ }^{13} \mathrm{C}\right)$ isotope discrimination $(\Delta)$ in grains was also positively correlated with yield progress, but other leaf traits such as flag leaf area, specific leaf weight, percentage nitrogen and greenness were not, nor was crop growth rate around anthesis. It was concluded, therefore, that $g_{s}$ and CTD should be further investigated as potential indirect selection criteria for yield.

Richards (2000) reviewed progress in cereal improvement and discussed the possible role of some selectable plant traits that may indirectly increase crop photosynthesis and grain yields. Among these traits are high $g_{s}$ during stem elongation and greater photoassimilate partitioning to the reproductive primordia so as to establish a large potential grain-sink.

Shankar et al. (1990) screened genetically 400 diverse lines of finger millet ( $\mathrm{a}_{4}$ crop) in India for assessing genetic variability in crop growth rate, net assimilation rate, leaf area, stomatal characteristics and leaf gas exchanges. In genotypes with similar dry matter production and harvest indices but differing in leaf area/ total dry matter ratio (LA/DM), leaf photosynthetic rates were $45 \%$ higher in genotypes with lower LA/DM than in genotypes with higher ratios. A significant negative correlation $(r=-0.87)$ existed between leaf photosynthetic rate and LA/DM ratio, suggesting that higher net assimilation rates could be attributed to leaf photosynthetic characteristics rather than dark respiration. The authors outlined a breeding scheme based on selecting lines high in both photosynthetic and crop growth rates and with low LA/DM ratios targeted to rainfed conditions. The lower LA/DM ratio, supposedly without effect on grain yield, and higher leaf photosynthetic rate would be beneficial in water-limited environments where total crop transpirational water loss will be lower and WUE higher.

Rmanujam (1990) working with cassava in India reported significant positive correlations between leaf photosynthetic rates measured in the field and tuber yield under irrigation. El-Sharkawy and coworkers (ElSharkawy et al., 1990, 1993; Pellet and El-Sharkawy, 1993; de Tafur et al., 1997; El-Sharkawy, 2004, 2006) screened large cassava breeding populations, including commercial varieties, land races and breeding lines for photosynthesis and productivity, under sub-humid, seasonally dry and semiarid environments in Colombia. They found positive correlations between upper canopy leaf photosynthesis, measured during four to six months after planting, and both total biomass and dry root yield. The correlations were chiefly attributed to nonstomatal factors (biochemical and/or anatomical features). Root dry yield was positively correlated with photosynthetic nitrogen-use efficiency (i.e., photosynthetic rate per unit total leaf nitrogen), and negatively with $C_{i}$. In a two-year trial in a seasonally dry environment, both root yields and leaf photosynthetic rates of 16 clones (selected from 127 tested in the first year) were positively correlated with rates in the first year (El-Sharkawy et al., 1990). Moreover, under prolonged stress in the field, leaf photosynthesis was associated with activities of the $\mathrm{C}_{4}$ enzyme PEPC in extracts of the same leaves. Analysis of $\Delta$ in 15 cultivars showed a significant negative correlation with photosynthetic rate of the same leaves, thus providing further evidence for the possible role of PEPC in cassava photosynthesis. These findings support the great potential for the selection for high leaf photosynthesis in breeding programs. Several parental materials with high photosynthetic rates were identified for inclusion in crosses to select for efficient lines in different ecosystems. Nevertheless, to be effective, selection for high leaf photosynthesis should be combined with other yield components and canopy leaf area. In cassava, harvest index (root yield/ total biomass), storage roots per plant, and leaf area duration were positively correlated with productivity (Pellet and El-Sharkawy, 
1993; El-Sharkawy, 2006). Genetic variations in leaf anatomy and activities of photosynthesis enzymes of wild Manihot should be evaluated in breeding programs (El-Sharkawy, 2004, 2006).

Because of the many components involved in the photosynthetic process, it will be more practical to identify rate-limiting factors for further studies and improvement. Noteworthy in this regard is the research on molecular engineering of $\mathrm{C}_{4}$ photosynthesis (Matsuoka et al., 1994, 2001) and the attempt to transform $\mathrm{C}_{3}$ rice by inserting the gene controlling $\mathrm{C}_{4}$ PEPC from maize (Ku et al., 1999). According to Ku (http:// www.biotech-info.net), such transgenic rice plants showed a high expression of PEPC within leaves, greater grain yield, and higher leaf photosynthetic rate per unit leaf area. The enhanced photosynthesis was mainly attributed to higher $g_{s}$ rather than to higher activity of PEPC. However, the high expression of PEPC in rice leaves, and hence its ability to recycle respiratory $\mathrm{CO}_{2}$, may have reduced, in this case, $C_{\mathrm{i}}$ under light. This effect can increase the $\mathrm{CO}_{2}$ gradient between air above leaf/ stomata and that within leaf mesophyll, thus leading to higher mesophyll conductance to $\mathrm{CO}_{2}$ diffusion (Gaastra, 1959). Higher mesophyll conductance would in turn lead to higher $\mathrm{CO}_{2}$ uptake rate. It is known that stomatal opening is controlled negatively by leaf $C_{\mathrm{i}}$, i.e., the higher the $\mathrm{CO}_{2}$ concentration in the sub-stomatal cavity the lesser the opening of stomata (Meidner and Mansfield, 1968). Thus, the higher $\mathrm{CO}_{2}$ photosynthetic rate observed in transgenic rice plants with the $\mathrm{C}_{4}$ PEPC of maize might be partially attributed to the enzyme's ability in directly fixing atmospheric $\mathrm{CO}_{2}$. Hopefully this kind of research may lead to a full expression and function of the $\mathrm{C}_{4}$ cycle in $\mathrm{C}_{3}$ plants.

Also, photosynthesis research laid the foundation of - and is still contributing to - crop modeling (de Wit, 1965; Duncan et al., 1967; Duncan, 1973; Baker, 1979; Loomis et al., 1979; Bunce, 1986; Penning de Vries et al., 1989; Baker and Landivar, 1991; Boote and Loomis, 1991). Such models, when built and calibrated on sound data from crops grown under field conditions, are useful tools for integrating research results at various organism levels, as well as for predicting crop responses to environmental conditions in different ecosystems (ElSharkawy, 2005). In view of apparent global climate changes, both photosynthesis research in agricultural and natural ecosystems and modeling will become increasingly important. It appears that $\mathrm{C}_{3}$ plants and crops will benefit relatively more from elevated $\mathrm{CO}_{2}$ than $\mathrm{C}_{4}$ species (Bazzaz, 1990; Chen et al., 1995a, Long et al., 2006) by restraining photorespiration, thus enhancing the carboxylation reaction by Rubisco in the $\mathrm{C}_{3}$ species. However, such increased photosynthetic activity is subject to many plant traits and environmental conditions that may result in a down-regulation in photosynthesis (i.e., reduced photosynthetic enhancement at elevated $\mathrm{CO}_{2}$ ) often observed in some species during long exposure to high $\mathrm{CO}_{2}$ (El-Sharkawy, 2005). Biological productivity is constrained by both abiotic factors such as soil, nutrients and water, and biotic factors such as pests and diseases. Moving potential yield up the curve requires alleviating these stresses as well as improving photosynthetic capacity of cultivated crops.

The above discussion indicates the hard work or research involved in developing an understanding of how leaves or crop canopies vary genetically in photosynthesis. Such an understanding of the processes involved there leads to explanatory models (Loomis et al., 1979) for process behavior, which possibly can be used to determine which process traits could be most efficiently improved in a breeding program. Such models need then to be improved with further research. The experimentalist in the field needs to thoroughly understand all the factors controlling various parts of a carbon, nitrogen, water and energy budget in the root-shoot-atmosphere system. Soil and atmospheric environment data should be taken over a growing season so the research can be used in a model. One cannot emphasize enough the importance of working out the factors involved in such budgets. Long et al. (2006) suggested that the water budget sub-model used in most models does not predict how plants cope with water stress in the field. Such discoveries are an important part of the progress of model development. Experimentalists lacking a good understanding of modeling theory may be aware of other factors that are not being treated properly in prevailing models. A detailed account of processes and factors involved in simulating soil-water-plant-atmosphere continuum can be found in the book of Penning de Vries et al. (1989). Also, the books by Loomis and Connor (1992) and 
Kirkham (2005) are useful references for more information in this regard.

Plant-soil-water relations and its implication for breeding for drought tolerance in water-limited environments: As stated by Kirkham (2005), out of the four soil physical factors affecting plant growth (i.e., mechanical impedance, water, aeration, and temperature), water is the most important. In most cropping systems and environments, water shortages or deficits, whether intermittent, recurrent, or prolonged occur under rainfed conditions (see Loomis and Connor, 1992). Plant survival and crop productivity are subject to the amount, pattern of distribution and availability of rainfall and soil-water for crop use. Simply stated, crop productivity is a function of the amount of water transpired (sometime including evaporation from uncovered soil), WUE and harvest index (de Wit, 1958; Fischer and Turner, 1978; Hanks and Rasmussen, 1982; Stanhill, 1986). In fact, plant-soil-water relations are likely to be one of the early and most studied subjects in plant and crop physiology [for more information see for example: Slatyer (1967); Nobel (1983, 1991); Kramer and Boyer (1995)].

Yet, criticism and controversy exist about the role and contribution of such research to plant breeding and crop improvement (Turner, 1986a; Ludlow and Muchow, 1990). Some of these shortcomings are attributed, partly, to a lack of appropriate methodology/technique to screen for large breeding populations in the field, to the complexity of mechanisms underlying plant responses to water deficit, and the related multiple plant traits to select for in genotypes tolerant to stress (that range from molecular to whole plant and crop community levels). Modeling the soil-plant-atmosphere continuum can partly help in identifying potential plant traits, processes and environmental factors involved (El-Sharkawy, 2005).

The easiest and most common approach in most breeding programs for selection to drought tolerance is to evaluate germplasm under the target environment using yield and/or yield stability as the main criteria for selection. The role of physiological research in this case is limited to identifying desirable plant traits that may confer some degree of tolerance to drought and, hence, could be incorporated individually or collectively into breeding materials. This approach can be further refined by advanced techniques, that can be easily managed in the field and handling large breeding population, such as canopy heat sensing, leaf chlorophyll fluorescence, leaf elemental isotope composition, and leaf gas exchange equipment. A comprehensive treatment of the many aspects of soil-plant-water-atmosphere interrelationships for many crops can be found in Stewart and Nielsen (1990) and Buxton et al. (1993). Also, research advances on WUE, responses to drought and possible mechanisms and plant traits related to drought tolerance, particularly in the last decades, have been reviewed in detail (Lange et al., 1976, 1982; Fischer and Turner, 1978; Walton 1980; Paleg and Aspinall, 1981; Morgan, 1984; Davies et al., 1986; Schulze, 1986a,b; Stanhill, 1986; Turner, 1986a,b; Passioura, 1988; Kreeb et al., 1989; Ludlow and Muchow, 1990; Boyer, 1996; McDonald and Davies, 1996).

Moreover, in studying drought physiology of crops, Kirkham (1983a,b), for example, developed a new research approach based on plant ideotype. Previously, researchers usually tried to identify drought-resistant cultivars by studying many different cultivars of unknown drought resistance. Kirkham, however, reversed the process and used two cultivars of winter wheat - one known to be drought resistant ('KanKing') and one known to be drought sensitive('Ponca') - and studied their physiology in detail. The goal was to answer the question "What are the characteristics of plants known to be drought resistant and how do they differ from plants known to be drought sensitive?" Kirkham and coworkers, in a series of publications (1978, $1979,1980,1981,1983 a, b, 1984)$, found that the droughtresistant cultivar had a higher stomatal resistance to water vapor diffusion, was more efficient in utilization of mineral elements in the soil, was more salt tolerant, had a different hormonal regulation (e.g., it was insensitive to abscisic acid and had lower water and osmotic potentials with ethephon), had a higher hydraulic resistance, and was better able to extract water from drying soil than the drought-sensitive cultivar. Furthermore, this work was expanded to consider drought-resistant and droughtsensitive cultivars of maize and sorghum (Kirkham et al., 1984; Kirkham, 1988).

There are several more examples that have followed, to some extent, the ideotype approach in identifying favorable plant traits for better adaptation to environment. These efforts have demonstrated some 
practical impact of physiological research on crop breeding for tolerance to drought. Most notably, breeding for various crops under water-limited environments including wheat in Australia, cowpea in India and Africa, sorghum and wheat in Israel, maize in Mexico, and cassava in tropical Africa and Latin America (Fischer and Turner, 1978; Richards and Passioura, 1981a,b; Morgan, 1984; Turner, 1986a; Blum and Sullivan, 1986; Blum, 1988, 1990, 1993; Cock and El-Sharkawy, 1988; Blum et al., 1989; Blum and Pnuel, 1990; Sedgely and Belford, 1991; Fukuda et al., 1992-1993; El-Sharkawy et al., 1992b; Hershey and Jennings, 1992; Bolaños and Edmeads, 1993a,b; Bolaños et al., 1993; Whan et al., 1993; El-Sharkawy, 1993, 2004, 2006; Madeley, 1994; de Tafur et al., 1997; Richards, 2000; El-Sharkawy and Cadavid, 2002; Hall, 2004).

The many plant traits associated with - and mechanisms underlying - tolerance to drought varied among plants with different growth habits, crops and trees, and with environmental conditions. Such mechanisms and traits included stress avoidance behavior as observed in coffee, and other woody species, via stomatal control of water loss during a dry period coupled with high atmospheric vapor-pressure deficits, and deep-rooting (Hernández et al., 1989; DaMatta and Ramalho, 2006); differential timing between female-ear silking and male-tassel pollen grain shedding in maize (Bolaños and Edmeads, 1993a,b; Bolaños et. al, 1993); and some osmotic adjustment and morphological and anatomical changes that affects leaf water loss such as cuticle waxing, leaf hairs and rolling, and root hydraulicresistance such as observed in cereals (Richards and Passioura, 1981a,b; Morgan, 1984; Passioura, 1988; Blum et al, 1989; Blum and Pnuel, 1990; Blum, 1993).

Research on cassava has revealed the many plant traits and mechanisms underlying crop tolerance to prolonged drought ( $>$ three months) in the tropics. Of paramount importance is the strong stomatal control over water losses under high evaporative demand conditions and water shortages. Cassava reacts rapidly to dry air by partially closing its stomata without major changes in bulk leaf water potential, and irrespective of soil water status (El-Sharkawy and Cock, 1984; El-Sharkawy et al., 1984). These striking responses were observed under both controlled laboratory conditions and in the field (Cock et al., 1985; El-Sharkawy, 1990, 1993, 2004, 2006).
Cassava is also capable of extracting soil water slowly from deep soil layers, while leaves are photosynthetically active at reasonable rates (e.g., stressed leaves had 40$70 \%$ of the photosynthetic rate in unstressed leaves), an advantage in a prolonged drought of several months. During drought, the leaf canopy is reduced via shedding lower leaves and by forming small-sized new leaves, and hence, less canopy light interception and water losses, another adaptive trait. After recovery from stress, in wet cycles, cassava rapidly compensates yield losses by forming a new canopy with even higher photosynthetic rates than that of unstressed crops (El-Sharkawy, 1993, 2004, 2006; Cayón, 1997). Under prolonged water shortage in the field, $\mathrm{C}_{4}$ PEPC activity is little changed or increased while the $\mathrm{C}_{3}$ Rubisco activity is significantly decreased resulting in a higher PEPC/Rubisco ratio. Under drought with stomata partially closed, PEPC effectively recycles internal respiratory $\mathrm{CO}_{2}$ (E1Sharkawy, 2004, 2006), a mechanism that may partially explain the reasonable yields under semiarid environments (Fukuda et al., 1992-1993; El-Sharkawy, 1993; de Tafur et al., 1997).

\section{FUNDING BASIC RESEARCH IN AGRICULTURE IS WARRANTED}

As discussed above, basic research in agriculture has made many major contributions during the $20^{\text {th }}$ century towards enhancement of biological productivity, food security and environmental quality improvement. Funding that research was modest compared to other areas of public spending in many developed countries, and its long-term annual economic return (benefit/cost ratio) was impressive and perhaps exceeded $25-30 \%$. The current excess of food production in developed countries is a clear testimony of the relevance of the role of basic research in enhancing agricultural productivity. Moreover, the Green Revolution of the 1960s saved some of the highly-populated countries, such as India and Pakistan, from possible famine (Athwal, 1971; Evenson and Gollin, 2003). In view of the anticipated human population growth in the coming few decades, increasing demands for food, feed and fibers must be urgently addressed (Sasson, 1990; Blake, 1994). Moreover, global climate changes that might negatively affect agricultural 
productivity in many parts of the world would further aggravate deficits in future food supply (Quebedeaux, 1990; Teramura, 1990; Teramura et al., 1990; Titus, 1990; Wittwer, 1990; Rosenzweig and Parry, 1994). Rosenzweig and Parry (1994), in assessing the effects of climate changes on cereal production, found that it will increase the current disparities between developed and developing countries. Thus, the developing countries will experience more deficits in their cereal crop production. They concluded that: "while some countries in the temperate zones may reap some benefit from climate change, many countries in the tropical and subtropical zones appear more vulnerable to the potential impacts of global warming". Since socio-economic benefits from basic research output, when finally translated at the market and society levels, normally takes at least 20 to 30 years, steadfast long-term funding is, therefore, warranted. Most funding for basic research in agriculture, which is unaffordable by resource-limited developing countries, has to come from both the public and private sectors in developed countries. These countries have the political and moral responsibility to compensate, partly, for the damaging effects of global climate changes that are mainly caused by their excessive consumption of fossil energy (IPCC, 2006, http:// www.grida.no/climate/ipcc/regional/502.htm). The multinational agrochemical companies, who are benefiting directly and/or indirectly from genetic diversity existing in many developing countries, particularly those in the tropics and subtropics with fauna -and flora- rich forests (Vaughan and Sitch, 1991), should freely recycle back some of their profits into supporting research in these countries.

Maintenance and highly applied research, including extension-type services, could be conducted by developing countries having well-established national research programs, and perhaps supported by some "non-research" oriented United Nations organizations. The current situation at CIAT, for example, has devoted more resources and effort into extension-type services at the expense of innovative basic research. "Bettermanage" international research centers, and committed innovative scientists, must devote their efforts into conducting both basic and applied research targeted to the fulfillment of the need of resource-limited countries. Hopefully with steadfast funding, this goal can be realized in close collaboration with national programs in developing countries and with advanced research institutions in developed countries in order to increase science output and efficiency (El-Sharkawy, 2005, 2006). At this point, scientists should be held accountable to taxpayers.

Wortman (1981), a visionary US citizen and plant breeder who spent a great part of his career in international agricultural research, pointed to the urgent need in supporting agricultural research and development for the benefit of developing countries. Wortman stated: "we as a nation can encourage our Agency for International Development, United Nations agencies such as the UNDP and FAO, and the World Bank and regional development banks to support efforts of the poorer and middle-income countries to accelerate production of staple foods (crops and livestock) and other primary agricultural products. Increasing world supply is crucial, and the scope of progress is enormous; in most countries, current yields are only a fraction of what they could be". I must add to this wise statement made by Wortman more than 25 years ago: developing countries, as well, should reform their socio-economic and political systems that are highly corrupt and abusive, so that the current high level of poverty could be alleviated. Population growth in developing countries also needs to be regulated. Without these needed reforms, science and technological advances will probably fail in alleviating poverty in developing countries (Leisinger, 1995). Again, as referred to in the introduction of this paper, the successful experience of the 2006 Nobel Peace laureate, Dr. Muhammad Yunus and his Grameen Bank micro-crediting system, is a case in point.

\section{CONCLUDING REMARKS}

The paper focused on - and discussed - (1) concerns over the role of basic research in the area of plant and crop ecophysiology and its impact on crop improvement, productivity and ecosystems management; (2) the limitations in applying useful physiological research findings into the agricultural production system; (3) the many previous achievements in crop improvement and management attributed to basic research; (4) the importance of integrating physiological research with plant breeding and other attendant sciences; and (5) the 
role of the more desirable and effective (and with more beneficial cost/benefit ratio) interdisciplinary/ interinstitutional research approach in solving problems constraining productivity at the farmer level. It also pointed to the need for providing and maintaining adequate funding for basic research focused on fulfilling the demand for improved technology for agricultural progress and food security, particularly in developing countries.

The human carrying capacity of mother earth is limited by: (1) the total available potential arable lands $(\approx 3-4$ billion hectares; Buringh, 1977); (2) the attainable crop productivity, which is normally below the potential; (3) the prevailing climatic conditions and its global changes in the near future; (4) and by the many other abiotic and biotic constraints. The projected world population, based on assumed different human-fertility levels, ranges (in round figures) from 8 to 13 billion by 2050 (Blake, 1994; Cohen, 1997). This anticipated increase in population points to the urgent need for an increasing agricultural productivity to secure and meet the expected food, feed and fiber demands. Such a goal requires immediate actions at the national and international levels. Given that the needed socio-economic reforms worldwide are fulfilled, adequately-funded agricultural research (both basic and applied) can increase crop productivity above the current levels and can ensure enough food, feed and fiber for the projected world population without the need to reclaim new less-arable lands nor raping the precious natural resources in tropical forests. Advances in science and technology are enormous and its proper application to agricultural development surely can pay off shortly within the $21^{\text {st }}$ century. Scientific research had already proved its success and utility in the $20^{\text {th }}$ century via the well-known agricultural "Green Revolution" that could be repeated over again. In the post-genomic era, and with obviating the negative and devastating effects of global climate changes, as now observed and documented (IPCC, 2006), the earth might become even greener and safer.

Finally, I wish to conclude with a very wise statement by Mahatma Gandhi: "Earth has enough for our needs but not enough for our greed".

Acknowledgements: I thank Mary Beth Kirkham, Kansas State University, Manhattan, John D. Hesketh, ARS/
USDA - University of IL, Urbana, Fábio DaMatta, editorin-chief, BJPP, Federal University of Viçosa, Brazil, for their inputs. The help of Farah El-Sharkawy Navarro in searching the internet for references and information and typing the manuscript was appreciated.

\section{REFERENCES}

Acock B, Acock M (1993) Modeling approaches for predicting crop responses to climate changes. In: Buxton DR, Shibles R, Forsberg RA, Blad BL, Asay KH, Paulsen GM, Wilson RF (eds), International Crop Science I., pp.299-306. Crop Science Society of America, Madison.

Akita S (1976) Photorespiration and its effect on dry matter production. JARQ 10:1-6.

Andries JA, Jones JE, Sloan LW, Marshall JG (1969) Effects of okra leaf shape on boll rot, yield, and other important characters of upland cotton, Gossypium hirsutum L. Crop Sci. 9:705-710.

Andries JA, Jones JE, Sloan LW, Marshall JG (1970) Effects of super okra leaf shape on boll rot, yield, and other characters of upland cotton, Gossypium hirsutum L. Crop Sci. 10:403-407.

Antonious GF, Kasperbauer MJ, Byers ME (1996) Light reflected from colored mulches to growing turnip leaves affects glucosinolate and sugar contents of edible roots. Photochem. Photobiol. 64:605-610.

Arjunan A, Natarajaratnam N, Nagarajan M, Sadasivam R (1990) Photosynthesis and productivity in rice cultivars. Photosynthetica 24:273-275.

Arp WJ (1991) Effects of source-sink relations on photosynthetic acclimation to elevated $\mathrm{CO}_{2}$. Plant Cell Environ. 14:869-875.

Arteca RN (1995) Plant Growth Substances-Principles and Applications. Springer, Berlin.

Ashley DA, Boerma HR (1989) Canopy photosynthesis and its association with seed yield in advanced generations of a soybean cross. Crop Sci. 29:1042-1045.

Athwal DS (1971) Semidwarf rice and wheat in global food needs. Quart. Rev. Biol. 46:1-34.

Austin RB (1993) Crop photosynthesis: can we improve on nature? In: Buxton DR, Shibles R, Forsberg RA, Blad BL, Asay KH, Paulsen GM, Wilson RF (eds), International Crop Science, pp.697-701. Crop Science Society of America, Madison.

Baker DN (1979) Simulation for research and crop management. In: Corbin FT (ed), World Soybean Research Conference II: Proceedings, pp.533-446. Westview Press, Boulder.

Baker DN, Landivar JA (1991) The simulation of plant development in GOSSYM. In: Hodges T (ed), Predicting Crop Phenology, pp.153-170. CRC Press, Boca Raton. 
Baker DN, Musgrave RB (1964) Photosynthesis under field conditions. V. Further plant chamber studies of the effects of light on corn (Zea mays L.). Crop Sci. 2:127-131

Baker NR, Davies WJ (1995) Control of Plant Growth. Cambridge University Press, Cambridge.

Balakrishnan K, Natarajaratnam N, Rajendran C (1987) Influence of sowing date on photosynthesis and production of Cajanus cajan (L.) Millsp. Photosynthetica 21:308-313.

Balls WL (1907) Mendelian studies of Egyptian cotton. J. Agric. Sci. 2:346-379.

Balls WL (1915) Development and Properties of Raw Cotton. A.\&C. Black Ltd., London.

Bassham JA (1977) Increasing crop production through more controlled photosynthesis. Science 197:630-638.

Bartels D, Nelson D (1994) Approaches to improve stress tolerance using molecular genetics. Plant Cell Environ. 17:659-667.

Bazzaz FA (1990) The response of natural ecosystems to the rising global $\mathrm{CO}_{2}$ levels. Anuu. Rev. Ecol. Syst. 21:167-196.

Begonia GB, Begonia MT (2007) Photosynthesis as controlled by leaf growth, phenology, and behavior - a brief historical review. Photosynthetica (in press).

Begonia GB, Begonia MFT, Ousby BR, Johnson M (1999) Vegetative and reproductive responses of cotton to state-specific $\mathrm{CO}_{2}$ enrichment and drought stress. J. Mississippi Acad. Sci. 44:190-196.

Begonia GB, Hesketh JD, Woolley JT, Peters DB (1987) Variability in leaf photosynthetic $\mathrm{CO}_{2}$ exchange rates near saturating irradiance and $\mathrm{CO}_{2}$. Photosynthetica 21:584-587.

Begonia GB, Russ B, Cunningham SG, Moore R (1996) Evidence of net photosynthetic acclimation to cotton exposed to state-specific $\mathrm{CO}_{2}$ enrichment. J. Mississippi Acad. Sci. 41:95-98.

Bernier G (1988) The control of floral evocation and morphogenesis. Annu. Rev. Plant Physiol. 39:175-219.

Berntson GM, McConnaughay KDM, Bazzaz FA (1993) Elevated $\mathrm{CO}_{2}$ alters deployment of roots in "small" growth containers. Oecologia 94:558-564.

Besford RT, Ludwig LJ, Withers AC (1990) The greenhouse effect: acclimation of tomato plants growing in high $\mathrm{CO}_{2}$, photosynthesis and ribulose-1,5-bisphosphate carboxylase protein. J. Exp. Bot. 229:925-931.

Bhagsari AS (1990) Relationship of photosynthesis and harvest index to sweet potato yield. J. Amer. Soc. Hort. 115:288-293.

Black CC, Jr. (1973) Photosynthetic carbon fixation in relation to net $\mathrm{CO}_{2}$ uptake. Annu. Rev. Plant Physiol. 24:253-286.
Black CC, Jr., Goldstein LD, Ray TB, Kestler DP, Mayne BC (1976) The relationship of plant metabolism to internal leaf and cell morphology and to the efficiency of $\mathrm{CO}_{2}$ assimilation. In: Burris RH, Black CC, Jr. (eds), Metabolism and Plant Productivity, pp.113-139. University Park Press, Baltimore.

Blake RO (1994) Feeding 10 billion people in 2050: The key role of the CGIAR's international agricultural research centers. Washington, D.C.: Action Group on Food Security, World Resources Institute.

Blum A(1988) Plant Breeding for Stress Environments. CRC Press, Boca Raton.

Blum A (1990) Variation among wheat cultivars in the response of leaf gas exchange to light. J. Agric. Sci. 115:305-311.

Blum A (1993) Selection for sustained production in waterdeficit environments. In: Buxton DR, Shibles R, Forsberg RA, Blad BL, Asay KH, Paulsen GM, Wilson RF (eds), International Crop Science. I. pp.343-347. Crop Science Society of America, Madison.

Blum A, Pnuel Y(1990) Physiological attributes associated with drought resistance of wheat cultivars in a Mediterranean environment. Aust. J. Agric. Res. 41:799810.

Blum A, Sullivan CY (1986) The comparative drought resistance of landraces of sorghum and millet from dry and humid regions. Ann. Bot. 57:835-846.

Blum A, Mayer J, Golan G (1989) Agronomic and physiological assessments of genotypic variation for drought resistance in sorghum. Aust. J. Agric. Res. 40:49-61.

Boerma HR, Ashley DA (1988) Canopy photosynthesis and seed-fill duration in recently developed soybean cultivars and selected plant introduction. Crop Sci. 28:137-140.

Bohnert HJ, Nelson DE, Jensen RG (1995) Adaptation to environmental stresses. Plant Cell 7:1099-1111.

Bolaños J, Edmeads GO (1993a) Eight cycles of selection for drought tolerance in lowland tropical maize. I. Responses in grain yield, biomass, and radiation utilization. Field Crops Res. 31:233-252.

Bolaños J, Edmeads GO (1993b) Eight cycles of selection for drought tolerance in lowland tropical maize. II. Responses in reproductive behavior. Field Crops Res. 31:253-268.

Bolaños J, Edmeads GO, Martinez L (1993) Eight cycles of selection for drought tolerance in lowland tropical maize. III. Responses in drought-adaptive physiological and morphological traits. Field Crops Res. 31:269-286.

Boote KJ, Loomis RS (1991) Modeling Crop Photosynthesis from Biochemistry to Canopy. Crop Science Society of America and American Society of Agronomy, Madison. 
BOSTID (1984) Amaranth-Modern Prospects for Ancient Crop. National Academy Press, Washington, D.C.

Boyer JS (1996) Advances in drought tolerance in plants. Adv. Agron. 56:187-218.

Brown DD (1983) How modern methods are solving biological problems. In: Owens LD (ed), Genetic Engineering: Applications to Agriculture (Beltsville Symposium 7), pp.1-11. Roman\& Allanheld, Granada.

Bunce JA (1986) Measurements and modeling of photosynthesis in field crops. Crit. Rev. Plant Sci. 4:47-77.

Bunce JA, Sicher RC Jr. (2004) Daily irradiance and feedback inhibition of photosynthesis of elevated carbon dioxide in Brassica oleracea. Photosynth. Res. 41:481-488.

Buringh P (1977) Food production potential of the world. World Develop. 5:477-485.

Buttery BR, Buzzell RI, Findlay WI (1981) Relationships among photosynthetic rate, bean yield and other characters in field-grown cultivars of soybean. Can. J. Plant Sci. 61:191-198.

Buxton DR, Shibles R, Forsberg RA, Blad BL, Asay KH, Paulsen GM, Wilson RF (1993) (eds), International Crop Science. I. Crop Science Society of America, Madison.

Casal JJ, Sánchez RA, Botto JF (1998) Models of action of phytochromes. J. Exp. Bot. 49:127-138.

Cayón MG, El-Sharkawy MA, Cadavid LF (1997) Leaf gas exchange of cassava as affected by quality of planting material and water stress. Photosynthetica 34:409-418.

Ceccarelli S, Grando S (1993) From conventional plant breeding to molecular biology. In: Buxton DR, Shibles R, Forsberg RA, Blad BL, Asay KH, Paulsen GM, Wilson RF (eds), International Crop Science. I., pp.533-537. Crop Science Society of America, Madison.

Chambers R, Jiggins J (1987) Agricultural research for resource-poor farmers Part I: Transfer-of-technology and farming systems research. Agric. Admin. Exten. 27:35-52.

Chambers R, Pacy A, Thrupp LA (1989) Farmer First: Farmer Innovation and Agricultural Research. Intermediate Technology Publications, London.

Chang TT (1976) The rice cultures. Phil. Trans. R. Soc. London B275:143-155.

Chang TT, Zuro C, Marciano-Romena A, Loresto GC (1967) Semi dwarfing genes in rice germplasm collection-Rice Genetic Newsletter. Vol. 1-3, IRRI, Los Baños, Philippines.

Chen XM, Alm DM, Hesketh JD (1995a) Effects of atmospheric $\mathrm{CO}_{2}$ concentration on photosynthetic performance of $\mathrm{C}_{3}$ and $\mathrm{C}_{4}$ plants. Biotronics 24:65-72.

Chen XM, Begonia GB, Alm DM, Hesketh JD (1993) Responses of soybean leaf photosynthesis to $\mathrm{CO}_{2}$ and drought. Photosynthetica 29:447-454.

Chen XM, Begonia GB, Hesketh JD (1995b) Soybean stomatal acclimation to long-term exposure to $\mathrm{CO}_{2}$ enriched atmospheres. Photosynthetica 31:51-57.
Chopra VL, Peter KV (2005) (eds), Handbook of Industrial Crops. Food Products Press, The Haworth Reference Press, Imprints of The Haworth Press, New York.

Cock JH, El-Sharkawy MA (1988) Physiological characteristics for cassava selection. Exp. Agric. 24:443-448.

Cock JH, Franklin D, Sandoval G, Juri P (1979) The ideal cassava plant for maximum yield. Crop Sci. 19:271-279.

Cock JH, Porto MCM, El-Sharkawy MA (1985) Water use efficiency of cassava. III. Influence of air humidity and water stress on gas exchange of field grown cassava. Crop Sci. 25:265-272.

Cohen JI (1993) An international initiative in biotechnology: priorities, values, and implementation of an A.I.D. project. Crop Sci. 33:913-918.

Cohen JE (1997) Population, economics, environment and culture: an introduction to human carrying capacity. J. Agric. Ecol. 34:1325-1333.

Connor JK, Gartner RJW, Runge BM, Amos RN (1980) Amaranthus edulis: an ancient food source re-examined. Aust. J. Exp. Agric. Anim. Husb. 20:156-161.

Cowling SA, Field CB (2003) Environmental control of leaf area production: implication for vegetation and landsurface modeling. Global Biogeochem. Cycles 17:doi:10.1029/2002GB001,915.

Critchfield R (1982) Science and the villager: the last sleeper wakes. Foreign Affairs 61:14-41.

DaMatta FM, Ramalho JDC (2006) Impacts of drought and temperature stress on coffee physiology and production: a review. Braz. J. Plant Physiol. 18:55-81.

Davies WJ, Zhang J (1991) Root signals and the regulation of growth and development of plants in drying soil. Annu. Rev. Plant Physiol. 42:55-76.

Davies WJ, Metcalfe J, Lodge TA, da Costa AR (1986) Plant growth substances and the regulation of growth under drought. Aust. J. Plant Physiol. 13:105-125.

Davis PJ (2005) Plant Hormones. Springer, Berlin.

Day P (1993) Integrating plant breeding and molecular biology: accomplishments and future promise. In: Buxton DR, Shibles R, Forsberg RA, Blad BL, Asay KH, Paulsen GM, Wilson RF (eds), International Crop Science. I., pp.517-523. Crop Science Society of America, Madison.

Delmer DP (2005) Agriculture in the developing world: connecting innovations in plant research to downstream applications. Proc. Natl. Acad. Sci. USA 102:15739-15746.

De Tafur SM, El-Sharkawy MA, Calle F (1997) Photosynthesis and yield performance of cassava in seasonally dry and semiarid environments. Photosynthetica 33:233-239.

De Veau EJ, Burris JE (1989) Photorespiratory rates in wheat and maize as determined by ${ }^{18} \mathrm{O}$-labeling. Plant Physiol. 90:500-511. 
De Wit CT (1958) Transpiration and Crop Yields, No. 64.6. Verslag van Lanbouwk, Donderzock.

De Wit CT (1965) Photosynthesis of leaf canopies. Agr. Res. Rep. (Pudoc-Wageningen) 663:1-57.

Donald CM (1968) The breeding of crop ideotype. Euphytica 17:385-403.

Duncan WG (1973) SIMCOT: A simulation of cotton growth and yield. In: Murphy C, Hesketh JD, Strain B (eds), Modeling the Growth of Trees, pp.115-118. Oak Ridge National Laboratory, Oak Ridge.

Duncan WG, Loomis RS, Williams WA, Hanau R (1967) A model for simulating photosynthesis in plant communities. Hilgardia 38:181-205.

Dwelle RB, Kleinkopf GE, Steinhorst RK, Pavek JJ, Hurley PJ (1981) The influence of physiological processes on tuber yield of potato clones (Solanum tuberosum L.): stomatal diffusive resistance, stomatal conductance, gross photosynthesis, leaf canopy, tissue nutrient levels, and tuber enzyme activities. Potato Res. 24:33-47.

Eaton FM (1927) Defruiting as an aid in cotton breeding. J. Hered. 18:454-460.

Eaton FM (1931a) Root development as related to character of growth and fruitfulness of the cotton plant. J. Agric. Res. 43:875-883.

Eaton FM (1931b) Early defloration as a method of increasing cotton yields and the relation of fruitfulness to fiber and boll characters. J. Agric. Res. 43:447-463.

Eaton FM (1955) Physiology of the cotton plant. Annu. Rev. Plant Physiol. 6: 299-328.

Eaton FM, Ergle DR (1952) Fiber properties and carbohydrate and nitrogen levels of cotton plants as influenced by moisture supply and fruitfulness. Plant Physiol. 27:541-562.

Eaton FM, Ergle DR (1954) Effects of shade and partial defoliation on carbohydrate levels and the growth, fruiting and fiber properties of cotton plants. Plant Physiol. 29:39-49.

Edwards G, Walker D (1983) $\mathrm{C}_{3}, \mathrm{C}_{4}$ : Mechanisms, and Cellular and Environmental Regulation of Photosynthesis. Blackwell Scientific, Oxford.

El-Sharkawy MA (1975) Crop Research in Kufra Oasis, Libya. Agricultural Development Council, Tripoli.

El-Sharkawy MA (1990) Effect of humidity and wind on leaf conductance of field grown cassava. Rev. Bras. Fisiol. Veg. 2:17-22.

El-Sharkawy MA (1993) Drought-tolerant cassava for Africa, Asia, and Latin America: breeding projects work to stabilize productivity without increasing pressures on limited natural resources. BioScience 43:441-451.

El-Sharkawy MA (2004) Cassava biology and physiology. Plant Mol. Biol. 56:481-501.

El-Sharkawy MA (2005) How can calibrated researchbased models be improved for use as a tool in identifying genes controlling crop tolerance to environmental stresses in the era of genomics - from an experimentalist's perspective. Photosynthetica 43:161176.

El-Sharkawy MA (2006) International research on cassava photosynthesis, productivity, eco-physiology, and responses to environmental stresses in the tropics. Photosynthetica 44:481-512.

El-Sharkawy MA, Cadavid LF (2002) Response of cassava to prolonged water stress imposed at different stages of growth. Exp. Agric. 38:333-350.

El-Sharkawy MA, Cock JH (1984) Water use efficiency of cassava. I. Effects of air humidity and water stress on stomatal conductance and gas exchange. Crop Sci. 24:497-502.

El-Sharkawy MA, Cock JH (1987) Response of cassava to water stress. Plant Soil 100:345-360.

El-Sharkawy MA, Cock JH, Held KAA (1984) Water use efficiency of cassava. II. Differing sensitivity of stomata to air humidity in cassava and other warm-climate species. Crop Sci. 24:503-507.

El-Sharkawy MA, Cock JH, Lynam JK, Hernández A del P, Cadavid LF (1990) Relationships between biomass, rootyield and single-leaf photosynthesis in field-grown cassava. Field Crops Res. 25:183-201.

El-Sharkawy MA, de Tafur SM, Cadavid LF (1992a) Potential photosynthesis of cassava as affected by growth conditions. Crop Sci. 32:1336-1342.

El-Sharkawy MA, de Tafur SM, Cadavid LF (1993) Photosynthesis of cassava and its relation to crop productivity. Photosynthetica 28:431-438.

El-Sharkawy MA, Hernández A del P, Hershey C (1992b) Yield stability of cassava during prolonged mid-season water stress. Exp. Agric. 28:165-174.

El-Sharkawy MA, Hesketh JD (1964a) Effects of temperature and water deficit on leaf photosynthetic rates of different species. Crop Sci. 4:514-518.

El-Sharkawy MA, Hesketh JD (1964b) Effect of stomatal differences among species on leaf photosynthesis. Crop Sci. 4:619-621.

El-Sharkawy MA, Hesketh JD (1965) Photosynthesis among species in relation to characteristics of leaf anatomy and $\mathrm{CO}_{2}$ diffusion resistances. Crop Sci. 5:517-521.

El-Sharkawy MA, Hesketh JD (1986) Citation ClassicPhotosynthesis among species in relation to characteristics of leaf anatomy and $\mathrm{CO}_{2}$ diffusion resistances. Curr. Cont. / Agric. Biol. Environ. 27:14.

El-Sharkawy MA, Hesketh JD, Muramuto H (1965) Leaf photosynthetic rates and other growth characteristics among 26 species of Gossypium. Crop Sci. 5:173-175.

El-Sharkawy MA, Loomis RS, Williams WA (1967) Apparent reassimilation of respiratory carbon dioxide by different plant species. Physiol. Plant. 20:171-186. 
El-Sharkawy MA, Loomis RS, Williams WA (1968) Photosynthetic and respiratory exchanges of carbon dioxide by leaves of the grain amaranth. J. Appl. Ecol. 5:243-251.

El-Tobgy HA (1974) Contemporary Egyptian Agriculture. Ford Foundation, Beirut.

Evans LT (1977) The plant physiologist as midwife. Search 8:262-268.

Evans LT (1993a) Crop Evolution, Adaptation and Yield. Cambridge University Press, Cambridge.

Evans LT (1993b) Processes, genes, and yield potential. In: Buxton DR, Shibles R, Forsberg RA, Blad BL, Asay KH, Paulsen GM, Wilson RF (eds), International Crop Science. I., pp.687-696. Crop Science Society of America, Madison.

Evans LT, Wardlaw IF, King RW (1985) Plants and environment: two decades of research at the Canberra phytotron. Bot. Rev. 51:203-272.

Evenson RE, Gollin D (2003) Assessing the impact of the Green Revolution, 1960 to 2000. Science 300:758-762.

Fischer RA, Turner NC (1978) Plant productivity in the arid and semiarid zones. Annu. Rev. Plant Physiol. 29:277-317.

Fischer RA, Rees D, Sayre KD, Lu ZM, Condon AG, Saavedra AL (1998) Wheat yield progress associated with higher stomatal conductance and photosynthetic rate, and cooler canopies. Crop Sci. 38:1467-1475.

Forrester ML, Krotkov G, Nelson CD (1966) Effect of oxygen on photosynthesis, photorespiration and respiration in detached leaves. II. Corn and other monocotyledons. Plant Physiol. 41:428-431.

Francis CA (1989) Biological efficiencies in multiplecropping systems. Adv. Agron. 42:1-42.

Freeling M (1984) Plant transposable elements and insertion sequences. Annu. Rev. Plant Physiol. 35:277-298.

Fukuda WMG, Ender M, Iglesias C (1992-1993) Development of cassava germplasm for drier tropics and sub-tropical agro-ecosystems. Annual Report 19921993, Working Plan 1993-1994, CNPMF, EPAGRI, CIAT, Cruz das Almas, Brazil.

Gaastra P (1959) Photosynthesis of crop plants as influenced by light, carbon dioxide, temperature, and stomatal diffusion resistance. Meded. Landbougeschool (Wageningen) 59 (13):1-68.

Garfield E (1992) The effectiveness of American Society of Agronomy Journals: A Citationist's perspective. In: Research Ethics, Manuscript Review and Journal Quality, pp.1-13. ACS Misc. Publishers, ISI, Pennsylvania.

Gifford RM, Evans LT (1981) Photosynthesis, carbon partitioning, and yield. Annu. Rev. Plant Physiol. 32:485509.

Gifford RM, Morison JIL (1993) Crop responses to the global increase in atmospheric carbon dioxide concentration. In: Buxton DR, Shibels R, Forsberg RA,
Blad BL, Asay KH, Paulsen GM, Wilson RF (eds), International Science. I., pp.325-331. Crop Science Society of America, Madison.

Haberlandt G (1904) Physiologische Pflanzenanatomie. Engelmann, Leipzig.

Hall AE (2004) Breeding for adaptation to drought and heat in cowpea. Eur. J. Agron. 21:447-454.

Hall AE, Allen LH, Jr. (1993) Designing cultivars for the climatic conditions of the next century. In: Buxton DR, Shibles R, Forsberg RA, Blad BL, Asay KH, Paulsen GM, Wilson RF (eds), International Crop Science. I., pp.291-297. Crop Science Society of America, Madison.

Hamblin J (1993) The ideotype concept: useful or outdated?. In: Buxton RD, Shibles R, Forsberg RA, Blad BL, Asay KH, Paulsen GM, Wilson RF (eds), International Science. I., pp.589-597. Crop Science Society of America, Madison.

Hanks RJ, Rasmussen VP (1982) Predicting crop production as related to plant water stress. Adv. Agron. 35:193-215.

Hatch MD, Slack CR (1966) Photosynthesis by sugar-cane leaves. A new carboxylation reaction and the pathway of sugar formation. Biochem. J. 101:103-111.

Hatch MD, Slack CR (1970) Photosynthetic $\mathrm{CO}_{2}$-fixation pathways. Annu. Rev. Plant Physiol. 21:141-162.

Hatch MD (1992) I can't believe my luck. Photosynth. Res. 33:1-14.

Hay RKM (1990) Tansley Review No.26 - The influence of photoperiod on the dry-matter production of grasses and cereals. New Phytol. 116:233-254.

Hellin J, Bellon M, Badstue L (2006) Bridging the gaps between researchers' and farmers' realities. Leisa 22:6-8.

Hernández ADP, Cock JH, El-Sharkawy MA (1989) The responses of leaf gas exchange and stomatal conductance to air humidity in shade-grown coffee, tea, cacao as compared with sunflower. Rev. Bras. Fisiol. Veg. 1:155-161.

Hershey CH, Jennings DL (1992) Progress in breeding cassava for adaptation to stress. Plant Breed. Abstr. 62:823-831.

Hesketh JD, Musgrave RB (1962) Photosynthesis under field conditions. IV. Light studies with individual corn leaves. Crop Sci. 2:311-315.

Hesketh JD, Case SS, Nanda DK (1969) Environmental and genetic modification of leaf number of maize, sorghum and Hungarian millet. Crop Sci. 9:460-473.

Hesketh JD, Ogren WL, Hageman ME, Peters DB (1981) Correlations among leaf $\mathrm{CO}_{2}$-exchange rates, areas and enzyme activities among soybean cultivars. Photosynth. Res. 2:21-30.

Hesketh JD, Woolley JT, Peters DB (1984) Leaf photosynthetic $\mathrm{CO}_{2}$ exchange rates in light and $\mathrm{CO}_{2}$ enriched environments. Photosynthetica 18:536-540. 
Hunter RB (1993) The molecular biologist and the plant breeder: In: Buxton DR, Shibles R, Forsberg RA, Blad BL, Asay KH, Paulsen GM, Wilson RF (eds), International Crop Science. I., pp.529-531. Crop Science Society of America, Madison.

Idso SB, Kimball BA, Allen SG (1991) Net photosynthesis of sour orange trees maintained in atmospheres of ambient and elevated $\mathrm{CO}_{2}$ concentration. Agric. For. Meteorol. 54:95-101.

IPCC - Intergovernmental Panel on Climate Change (2006) IPCC Special Report on The Regional Impacts of Climate Change-An Assessment of Vulnerability, UNEP, WMO. (http://www.grida.no/climate/ipcc/regional/502.htm).

IRRI - International Rice Research Institute (1990) Program Report for 1989. IRRI, Los Baños, Philippines.

Jackson P, Robertson M, Cooper M, Hammer G (1996) The role of physiological understanding in plant breeding; from a breeding perspective. Field Crops Res. 49:11-37.

Jackson WA, Volk RJ (1969) Oxygen uptake by illuminated maize leaves. Nature 222:269-271.

Jackson WA, Volk RJ (1970) Photorespiration. Annu. Rev. Plant Physiol. 21:385-432.

Jennings PR (1964) Plant type as a rice breeding objective. Crop Sci. 4:13-15.

Jennings DL, Iglesias C (2002) Breeding for crop improvement. In: Hillocks RJ, Thresh JM, Bellotti AC (eds), Cassava: Biology, Production and Utilization, pp.149-166. CABI Publishing, New York.

Kanai R, Edwards GE (1999) Biochemistry of $\mathrm{C}_{4}$ photosynthesis. In: Sage RF, Monson RK (eds), The Biology of $\mathrm{C}_{4}$ Photosynthesis, pp.49-87. Academic Press, New York.

Karpilov YS (1960) The distribution of radioactivity in carbon-14 among products of photosynthesis in maize. Proc. Kazan Agric. Inst. 14:15-24.

Kasperbauer MJ (1999) Colored mulch for food crops. Chemtech 29:45-50.

Kasperbauer MJ (2000) Strawberry yield over red versus black plastic mulch. Crop Sci. 40:171-174.

Kasperbauer MJ, Hunt PG (1998) Far-red light affects photosynthate allocation and yield of tomato over red mulch. Crop Sci. 38:970-974.

Kawano K (2003) Thirty years of cassava breeding for productivity-biological and social factors for progress. Crop Sci. 43:1325-1335.

Kawano K, Cock JH (2005) Breeding cassava for underprivileged: institutional, socio-economic and biological factors for success. J. Crop Improv. 14:197-219.

Kawano K, Narintaraporn K, Narintaraporn P, Sarakarm S, Limsila A, Limsila J, Suparhan D, Sarawat V, Watananonta W (1998) Yield improvement in a multistage breeding program for cassava. Crop Sci. 38:325-332.
Kennedy CW, Smith WC Jr., Jones JE (1986) Effect of early season square removal on three leaf types of cotton. Crop Sci. 26:139-145.

Kirkham MB (1979) Effect of FeEDDHA on water relations of wheat. J. Plant. Nutr. 1:417-424.

Kirkham MB (1980) Efficiency of drought-resistant and drought-sensitive wheat cultivars in the use of elements in soil. Phyton 38:137-146.

Kirkham MB (1983a) Effect of ABA on the water relations of winter-wheat cultivars varying in drought resistance. Physiol. Plant. 59:153-157.

Kirkham MB (1983b) Effect of ethephon on the water status of a drought-resistant and a drought-sensitive cultivar of winter wheat. J. Plant Physiol. 112:103-112.

Kirkham MB (1984) Water relations of drought-resistant and drought-sensitive wheat cultivars sprinkled with saline water. Irrig. Sci. 5:137-146.

Kirkham MB (1988) Hydraulic resistance of two sorghums varying in drought resistance. Plant Soil 105:19-24.

Kirkham MB (2005) Principles of Soil and Plant Water Relations. Elsevier, New York.

Kirkham MB, Ahring RM (1978) Leaf temperature and internal water status of wheat grown at different root temperatures. Agron. J. 70:657-662.

Kirkham MB, Suksayretrup K, Wassom CE, Kanemasu ET (1984) Canopy temperature of drought-resistant and drought-sensitive genotypes of maize. Maydica 29:287303.

Kortchak HP, Hartt CE, Burr GO (1965) Carbon dioxide fixation in sugarcane leaves. Plant Physiol. 40:209-213.

Kramer PJ (1980) The role of physiology in crop improvement. In: Staples RC, Kuhr RJ (eds), Linking Research to Crop Production, pp.51-62. Plenum Press, New York.

Kramer PJ (1981) Carbon dioxide concentration, photosynthesis, and dry matter production. BioScience 31:29-33.

Kramer PJ, Boyer JS (1995) Water Relations of Plants and Soils. Academic Press, San Diego.

Kreeb KH, Richter H, Hinckley TM (1989) Structural and Functional Responses to Environmental Stresses: Water Shortage. SPB Academic Publ., The Hague.

Ku MSB, Agare S, Numora M, Fukayam H, Tsuchida S, Ono K, Hirose S, Toki S, Miyao M, Matsuoka M (1999) High level expression of maize phosphoenolpyruvate carboxylase in transgenic rice plants. Nature Biotechnol. 17:76-80.

Kutáček M, Elliott MC, Macháčková I (1990) Molecular Aspects of Hormonal Regulation of Plant Development. SPB Academic Publ., The Hague.

Laetsch WM (1974) The $\mathrm{C}_{4}$ syndrome: a structure analysis. Annu. Rev. Plant Physiol. 25:27-52. 
Lange OL, Kappen L, Schulze E-D (1976) Water and Plant Life: Problems and Modern Approaches. SpringerVerlag, New York.

Lange OL, Nobel PS, Osmond CB, Ziegler H (1982) Physiological Plant Ecology. II. Water Relations and Carbon Assimilation. Encyclopedia of Plant Physiology, New Series, Vol. 12 B. Springer-Verlag, New York.

Leisa (2006) Magazine on Low External Input and Sustainable Agriculture. (http://www.leisa.info).

Leisinger KM (1995) Sociopolitical effects of new biotechnologies in developing countries. Food, Agriculture, and the Environment Discussion Paper 2. International Food Policy Research Institute (IFPRI), Washington D.C.

Lenis JI, Calle F, Jaramillo G, Perez JC, Ceballos S, Cock JH (2006) Leaf retention and cassava productivity. Field Crops Res. 95:126-134.

Leopold C, Kriedmann PE (1975) Plant Growth and Development. McGraw-Hill, New York.

Loojin RC (1999) Holism and Reductionism in Biology and Ecology - The Mutual Dependence of Higher and Lower Level Research. Springer, Berlin.

Loomis RS, Connor DJ (1992) Crop Ecology. Cambridge University Press, Cambridge.

Loomis RS, Rabbinge R, Ng E (1979) Explanatory models in crop physiology. Annu. Rev. Plant Physiol. 30:339367.

Long SP, Ainsworth EA, Leakey ADB, Nösberger J, Ort DR (2006) Food for thought: lower-than-expected crop yield stimulation with rising $\mathrm{CO}_{2}$ concentration. Science 312: 1918-1921.

Ludlow MM, Muchow RC (1990) A critical evaluation of traits for improving crop yields in water-limited environments. Adv. Agron. 43:107-153.

Lupton FGH (1972) Further experiments of photosynthesis and translocation of ears and flag leaves of wheat and barley. Ann. Bot. 29:317-330.

Madeley J (1994) Breeding for the tough spots: CGIAR researchers are developing crops that thrive in the harshest of habitats. CERES - The FAO Review, Rome 26(5):22-26.

Mandava NB (1988) Plant growth-promoting brassinosteroids. Annu. Rev. Plant Physiol. 39:23-52.

Mazur BJ, Falco SC (1989) The development of herbicide resistant crops. Annu. Rev. Plant Physiol. 40: 441-470.

Matsuoka M, Furbank RT, Fukayama H, Miyao M (2001) Molecular engineering of $\mathrm{C}_{4}$ photosynthesis. Annu. Rev. Plant Physiol. Plant Mol. Biol. 52:297-314.

Matsuoka M, Kyozuka J, Shimamoto K, Kano-Murakami Y (1994) The promoters of two carboxylases in a $\mathrm{C}_{4}$ plant (maize) direct cell-specific, light-regulated expression in $\mathrm{a} \mathrm{C}_{3}$ plant (rice). Plant J. 6:311-319.
McBlain BA, Bernard RL (1987) A new gene affecting the time of flowering and maturity in soybeans. J. Hered. 78:160-162.

McBlain BA, Hesketh JD, Bernard RL (1987) Genetic effect on reproductive phenology in soybean isolines differing in maturity genes. Can. J. Plant Sci. 67:105-116.

McConnaughay KDM, Bernston GM, Bazzaz FA (1993) Plant response to carbon dioxide. Nature 361:24.

McClintock B (1942) The fusion of broken ends of chromosomes following nuclear fusion. Proc. Natl. Acad. Sci. USA 28:458-463.

McClintock B (1950) The origin and behavior of mutable loci in maize. Proc. Natl. Acad. Sci. USA 36:344-355.

McClintock B (1978) Mechanisms that rapidly reorganize the genome. Stadler Genet. Symp. 10:25-48.

McDonald AJS, Davies WJ (1996) Keeping in touch: responses of the whole plant to deficits in water and nitrogen supply. Adv. Bot. Res. 22:229-300.

Meidner H, Mansfield TA (1968) Physiology of Stomata. McGraw-Hill, London.

Monsi M, Saeki T (1953) Über den Lichtfaktor in den Pflanzen-gesellschaften und seine Bedeutung für die Stoffproduktion. Jap. J. Bot. 14:22-52.

Morgan JM (1984) Osmoregulation and water stress in higher plants. Annu. Rev. Plant Physiol. 35:299-319.

Moss DN, Musgrave RB (1971) Photosynthesis and crop production. Adv. Agron. 23: 317-336.

Muramoto H, Hesketh J, El-Sharkawy M (1965) Relationships among rate of leaf area development, photosynthetic rate, and rate of dry matter production among American cultivated cottons and other species. Crop Sci. 5:163-166.

Murfet IC (1977) Environmental interaction and the genetics of flowering. Annu. Rev. Plant Physiol. 28:253-278.

Murfet IC (1989) Flowering genes in Pisum. In: Lord E, Bernier G (eds), Plant Reproduction: from Floral Induction to Pollination, pp.10-18. American Society of Plant Physiology, Rockville.

Musgrave RB, Moss DN (1961) Photosynthesis under field conditions. I. A portable, closed system for determining net assimilation and respiration of corn. Crop Sci. 1:37-41.

Nasyrov YS (1978) Genetic control of photosynthesis and improving of crop productivity. Annu. Rev. Plant Physiol. 29:215-237.

Nasyrov YS (1981) Genetic modification of the $\mathrm{CO}_{2}$ carboxylation reactions as a factor improving efficiency of photosynthesis. Indian J. Plant Physiol. 24:26-36.

Nobel PS (1983) Biophysical Plant Physiology and Ecology. W.H. Freeman, San Francisco.

Nobel PS(1991) Physiochemical and Environmental Plant Physiology. Academic Press, San Diego.

Paleg LG, Aspinall D (1981) (eds) The Physiology and Biochemistry of Drought Resistance in Plants. Academic Press, Sidney. 
Passioura JB (1988) Water transport in and to roots. Annu. Rev. Plant Physiol. 39:245-265.

Paterson AH, Tanksley SD, Sorrells ME (1991) DNA markers in plant improvement. Adv. Agron. 46:39-90.

Patterson DT (1993) Implication of global climate change for impact of weeds, insects, and plant diseases. In: Buxton DR, Shibles R, Forsberg RA, Blad BL, Asay KH, Paulsen GM, Wilson RF (eds), International Crop Science. I., pp.273-280. Crop Science Society of America, Madison.

Pellet D, El-Sharkawy MA (1993) Cassava varietal response to phosphorus fertilization. I. Yield, biomass and gas exchange. Field Crops Res. 35:1-11.

Peng S, Krieg DR, Girma FS (1991) Leaf photosynthetic rate is correlated with biomass and grain production in grain sorghum lines. Photosynth. Res. 28:1-7.

Penning de Vries FWT, Jansen DM, Ten Berge HFM, Bakema A (1989) Simulation of Ecophysiological Processes of Growth in Several Annual Crops. PUDOC, Wageningen.

Peterson PA (1993) Transposable elements in maize: their role in creating plant genetic variability. Adv. Agron. 51:79-124.

Pettigrew WT (2004a) Physiological consequences of moisture deficit stress in cotton. Crop Sci. 44:1265-1272.

Pettigrew WT (2004b) Cotton genotypic variation in the photosynthetic response to irradiance. Photosynthetica 42:567-571.

Pettigrew WT, Heitholt JJ, Vaughn KC (1993) Gas exchange and comparative anatomy among cotton leaftype isolines. Crop Sci. 33:1295-1299.

Postel S (1984) Water: rethinking management in an age of scarcity. Worldwatch Paper 62. Worldwatch Institute, Washington, D.C.

Potrykus I (1991) Gene transfer to plants: assessment of published approaches and results. Annu. Rev. Plant Physiol. Plant Mol. Biol. 42:205-225.

Quail PH, Boylan MT, Parks BM, Short TW, Xu Y, Wagner D (1995) Phytochromes: photosensory perception and signal transduction. Science 268:675-680.

Quebedeaux B (1990) Implications of global climate changes on horticultural cropping practices and production in developing countries. HortScience 25:1556.

Quinby JR(1973) The maturity genes of sorghum. Adv. Agron. 19:267-305.

Quinby JR, Hesketh JD, Voight RL (1973) Influence of temperature and photoperiod on floral initiation and leaf number in sorghum. Crop Sci. 13:243-276.

Ramanujam T (1990) Effect of moisture stress on photosynthesis and productivity of cassava. Photosynthetica 24:217-224.
Raven JA (1972) Endogenous inorganic carbon source in plant photosynthesis. New Phytol. 71:995-1014.

Richards RA (2000) Selectable traits to increase crop photosynthesis and yield of grain crops. J. Exp. Bot. 51:447-458.

Richards RA, Passioura JB (1981a) Seminal root morphology and water use of wheat. I. Environmental effects. Crop Sci. 21:249-252.

Richards RA, Passioura JB (1981b) Seminal root morphology and water use of wheat. II. Genetic variation. Crop Sci. 21:253-255.

Ronchi CP, DaMatta FM, Batista KD, Moraes GABK, Loureiro ME, Ducatti C (2006) Growth and photosynthetic down-regulation in Coffea arabica in response to restricted root volume. Funct. Plant Biol. 33:1013-1023.

Rosenzweig C (1993) Recent global assessments of crop responses to climate change. In: Buxton DR, Shibles R, Forsberg RA, Blad BL, Asay KH, Paulsen GM, Wilson RF (eds), International Crop Science. I., pp.265-272. Crop Science Society of America, Madison.

Rosenzweig C, Parry ML (1994) Potential impact of climate change on world food supply. Nature 367:133-138.

Ruckenbauer P (1975) Photosynthetic and translocation pattern in contrasting winter wheat varieties. Ann. Appl. Biol. 79:351-359.

Ryder EJ (1984) The art and science of plant breeding in the modern world of research management. HortScience 19:808-811.

Saeki T (1960) Interrelationships between leaf amount, light distribution and leaf photosynthesis in a community. Bot. Mag. 37:5-63.

Sasson A (1990) Feeding Tomorrow's World. United Nations Educational, Scientific and Cultural Organization (UNESCO)/CTA, Paris.

Saunders RM, Becker R (1983) Amaranthus: a potential food and feed resource. Adv. Cereal Sci. Technol. 6: 357-396.

Schrader LE (1980) Contributions from biochemistry and plant physiology. In: Moving Up the Yield CurveAdvances and Obstacles, pp.25-43. American Society of Agronomy and Soil Science Society of America, Madison.

Schulze E-D (1986a) Carbon dioxide and water vapor exchange in response to drought in the atmosphere and the soil. Annu. Rev. Plant Physiol. 37:247-274.

Schultze E.-D (1986b) Whole-plant responses to drought. Aust. J. Plant Physiol. 13:127-141.

Sedgely RH, Belford RK (1991) (eds), Ideoptype and physiology: tailoring plants for increased production. Field Crops Res. 26:89-226.

Shankar AG, Kumar MU, Prasad TG (1990) Genetic variability for net photosynthesis in finger millet (Eleusine coracana Gaertn) genotypes-an approach to identify high CER types. J. Agron. Crop Sci. 165:240-252. 
Sholtis JD, Gunderson CA, Norby RJ, Tissue DT (2004) Persistent stimulation of photosynthesis by elevated $\mathrm{CO}_{2}$ in a sweetgum (Liquidamber styraciflua) forest stand. New Phytol. 162:343-354.

Shorter R, Lawn RJ, Hammer GL (1991) Improving genotypic adaptation in crops- a role for breeders, physiologists and modelers. Exp. Agric. 27:155-175.

Simmonds NW (1991) Bandwagons I have known. TAA Newslett. 11:7-10

Sinha S (1993) Response of tropical agroecosystems to climate change. In: Buxton DR, Shibles R, Forsberg RA, Blad BL, Asay KH, Paulsen GM, Wilson RF (eds), International Crop Science. I., pp.281-289. Crop Science Society of America, Madison.

Slatyer RO (1967) Plant Water Relationships. Academic Press, New York.

Somerville CR, Ogren WL (1980) Photorespiration mutants of Arabidopsis thaliana deficient in serine-glyoxylate aminotransferase activity. Proc. Natl. Acad. Sci. USA 77:2684-2687.

Somerville CR, Portis AR, Jr., Ogren WL (1982) A mutant of Arabidopsis thaliana which lacks activation of RuBP carboxylase in vivo. Plant Physiol. 70:381-387.

Snyder FW, Carlson GE (1984) Selection for partitioning of photosynthetic products in crops. Adv. Agron. 37:47-72.

Stanhill G (1986) Water use efficiency. Adv. Agron. 39:53-85.

Stewart BA, Nielson DR (1990) Irrigation of Agricultural Crops. ASA, CSSA, SSSA, Madison.

Tanksley SD, Young ND, Paterson AH, Bonierbale MW (1989) RFLP mapping in plant breeding: new tools for an old science. Bio/Technology 7:257-264.

Teramura AH (1990) Implications of stratospheric ozone depletion upon plant production. HortScience 25:15571560.

Teramura AH, Sullivan JH, Ziska LH (1990) Interaction of elevated Ultraviolet-B radiation and $\mathrm{CO}_{2}$ on productivity and photosynthesis in wheat, rice, and soybean. Plant Physiol. 94:470-475.

Thornley JHM, Johnson IR (1990) Plant and Crop Modelling: A Mathematical Approach to Plant and Crop Physiology. Oxford Sci. Publ., Clarendon Press, Oxford.

Tipton KW, El-Sharkawy MA, Thomas BM, Jones JE, Henderson MT (1964a) Inheritance of fiber elongation in two separate crosses of upland cotton having a common parent, pp.13-20. In: Proceedings of $16^{\text {th }}$ Annual Cotton Improvement Conference, National Cotton Council of America, Memphis, Tennessee.

Tipton KW, El-Sharkawy MA, Thomas BM, Jones JE, Henderson MT (1964b) Inheritance of fiber strength in two separate crosses of upland cotton having a common parent, pp.20-27. In: Proceedings of $16^{\text {th }}$ Annual Cotton Improvement Conference, National Cotton Council of America, Memphis, Tennessee.
Titus JG (1990) Effect of climate change on sea level rise and the implications for world agriculture. HortScience 25:1567-1572.

Turner NC (1986a) Crop water deficits: a decade of progress. Adv. Agron. 39:1-51.

Turner NC (1986b) Adaptation to water deficits: a changing perspective. Aust. J. Plant Physiol. 13:175-190.

Vaughan DA, Sitch LA (1991) Gene flow from the jungle to farmers: wild-rice genetic resources and their use. BioScience 41:22-28.

Virmani SS (1996) Hybrid rice. Adv. Agron. 57:377-462.

Vogel DA (1964) Registration of 'Gains Wheat' (Reg. No. 425). Crop Sci. 4:116-117.

von Caemmerer S, Furbank RT (1997) (eds), $\mathrm{C}_{4}$ photosynthesis: 30 (or 40) years on. Aust. J. Plant Physiol. 24:409-555.

Wallace JS (2000) Increasing agricultural water use efficiency to meet future food production. Agric. Ecosyst. Environ. 82:105-119.

Walton DC (1980) Biochemistry and physiology of abscisic acid. Annu. Rev. Plant Physiol. 31:453-489.

Wareing PF (1982) A plant physiological odyssey. Annu. Rev. Plant Physiol. 33:1-26.

Watson DJ (1947) Comparative physiological studies on the growth of field crops: I. Variation in net assimilation rate and leaf area between species and varieties, and within and between years. Ann. Bot. 41:41-76.

Watson DJ (1952) The physiological basis of variation in yield. Adv. Agron. 4:101-145.

Whan BR, Carlton GP, Siddique KHM, Regan KL, Turner NC, Anderson WK (1993) Integration of breeding and physiology: lessons from a water-limited environment. In: Buxton DR, Shibles R, Forsberg RA, Blad BL, Asay KH, Paulsen GM, Wilson RF (eds), International Crop Science. I., pp.607-614. Crop Science Society of America, Madison.

Whisler FD, Acock B, Baker DN, Fye RE, Hodges HF, Lambert JR, Lemmon HE, McKinion JM, Reddy VR (1986) Crop simulation models in agronomic systems. Adv. Agron. 40:141-208.

Wittwer SH (1979) Future technological advances in agriculture and their impact on the regulatory environment. BioScience 29:603-610.

Wittwer SH (1990) Implications of the greenhouse effect on crop productivity. HortScience 25:1560-1567.

Wortman S (1981) Beyond the Bottom Line. The Rockefeller Foundation, New York.

Wortman S, Cummings RW, Jr. (1978) To Feed This World: The Challenge and the Strategy. Johns Hopkins University Press, Baltimore.

Yoshida S (1972) Physiological aspects of grain yield. Annu. Rev. Plant Physiol. 23:437-464.

Zeevaart JAD (1962) Physiology of flowering. Science 137:723-731. 
Zeevaart JAD (1976) Physiology of flower formation. Annu. Rev. Plant Physiol. 27:321-348.

Zeevaart JAD, Creelman RA (1988) Metabolism and physiology of abscisic acid. Annu. Rev. Plant Physiol. 39:439-473.

Zelitch I (1975) Improving the efficiency of photosynthesis. Science 188:626-633.
Zelitch I (1982) The close relationship between net photosynthesis and crop yield. BioScience 32:796-801.

Ziska LH, Hogan KP, Smith AP, Drake BG (1991) Growth and photosynthesis response of nine tropical species with long-term exposure to elevated carbon dioxide. Oecologia 86:383-38 